\title{
Hydrogeology of the Beaver Kill Basin in Sullivan, Delaware, and Ulster Counties, New York
}

\section{U.S. GEOLOGICAL SURVEY}

WATER RESOURCES INVESTIGATIONS REPORT 00-4034

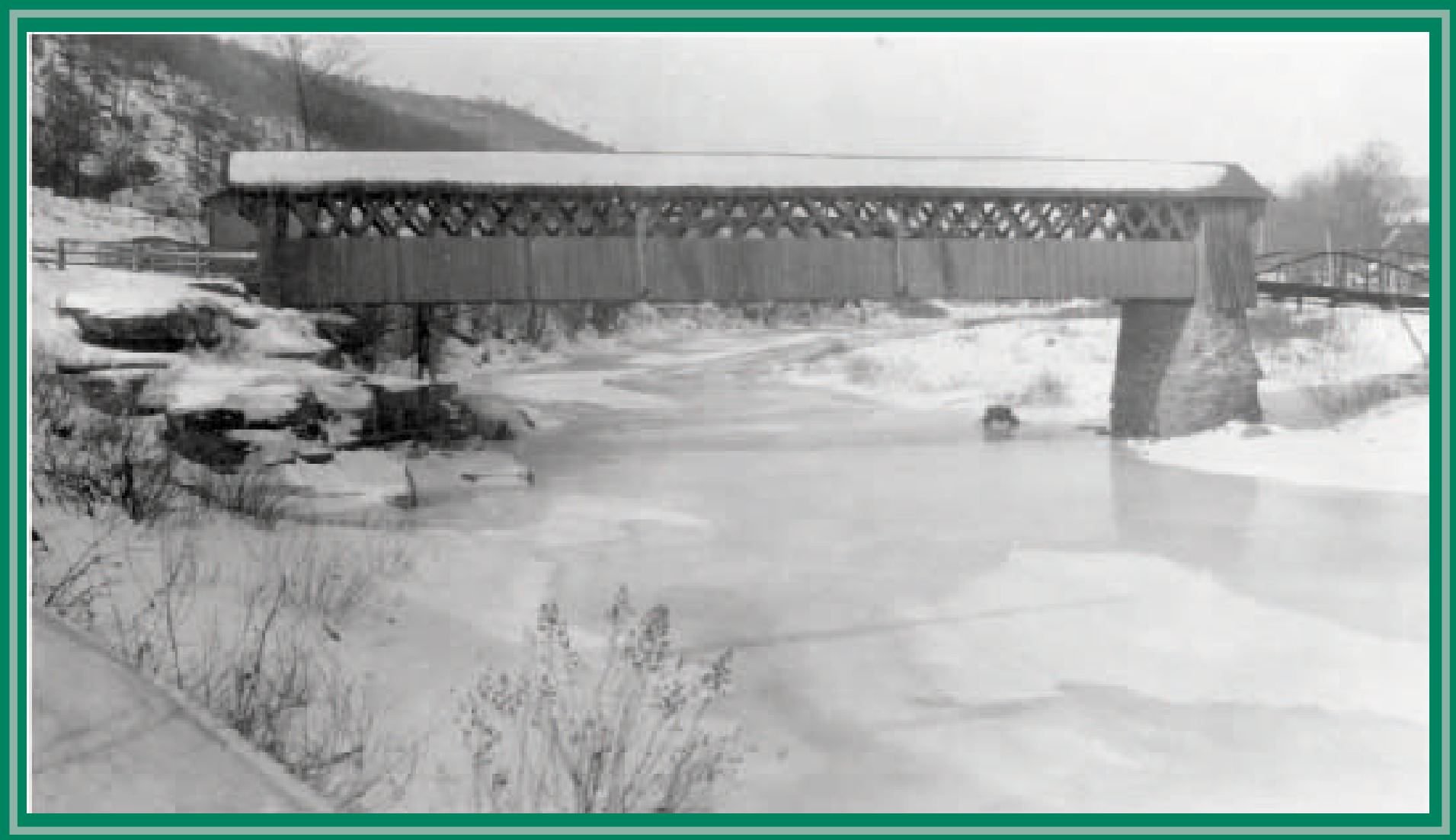

Prepared in cooperation with the TOWN OF ROCKLAND 
Cover: A covered bridge of the Town lattice-truss type spans the Beaver Kill at Cooks Falls, NY in January, 1918. Many of these covered bridges, built from the 1850's through the 1870 's, provided crossings for local roads across the Beaver Kill and Willowemoc Creeks through the early 1900 's. The U.S. Geological Survey has been collecting streamflow data at this site since July, 1913--making it one of the oldest stream-gaging sites in New York. (Photo from U.S. Geological Survey archives). 


\section{Hydrogeology of the Beaver Kill Basin in Sullivan, Delaware, and Ulster Counties, New York}

By Richard J. Reynolds

U.S. GEOLOGICAL SURVEY

Water-Resources Investigations Report 00-4034

Prepared in Coooperation with the

Town of Rockland

Troy, New York

2000 


\title{
U.S. DEPARTMENT OF THE INTERIOR BRUCE BABBITT, Secretary
}

\author{
U.S. GEOLOGICAL SURVEY
}

Charles G. Groat, Director

The use of firm, trade, and brand names in this report is for identification purposes only and does not constitute endorsement by the U.S. Geological Survey

For additional information write to:

U.S. Geological Survey

425 Jordan Road

Troy, NY 12180-8349
Copies of this report can be purchased from:

U.S. Geological Survey

Information Services

Box 25286

Federal Center

Denver, CO 80225 


\section{CONTENTS}

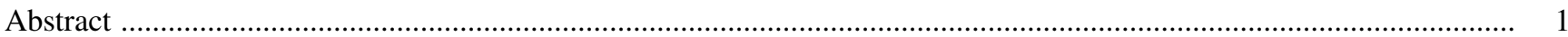

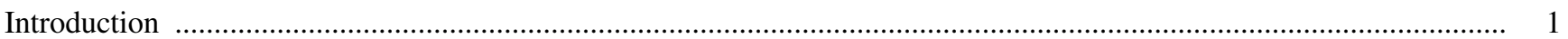

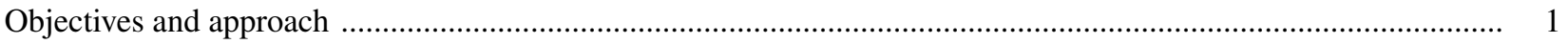

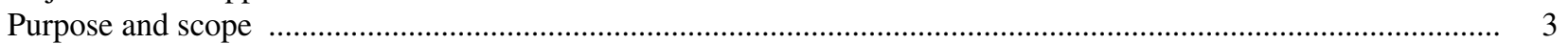

Geology

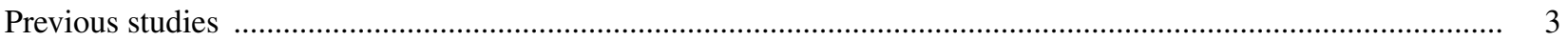

Surficial geologic units

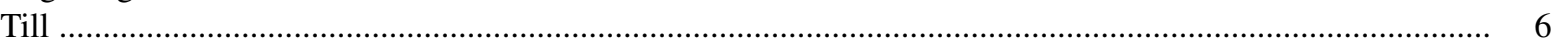

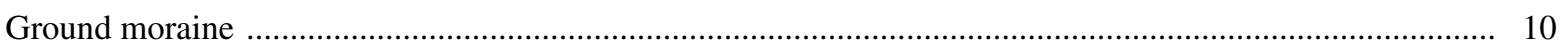

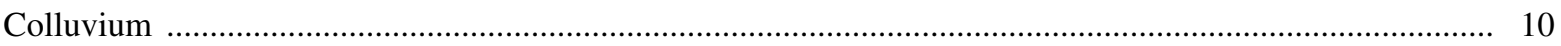

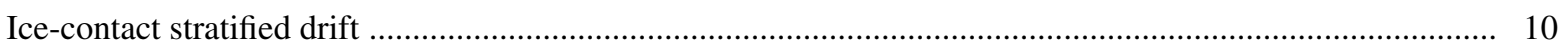

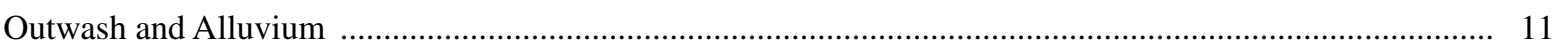

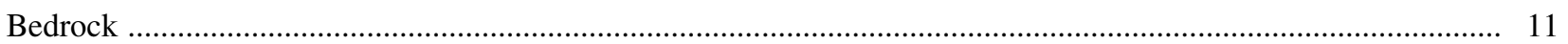

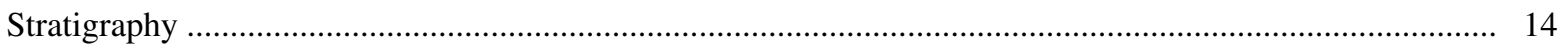

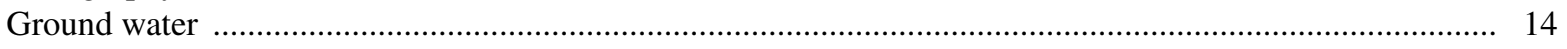

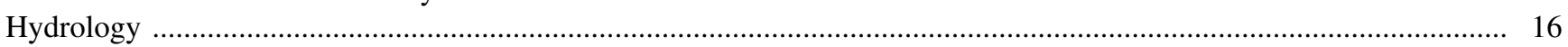

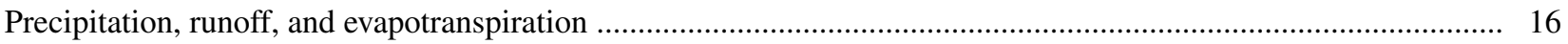

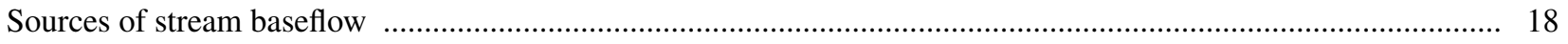

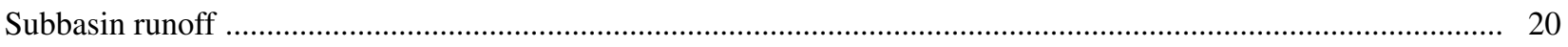

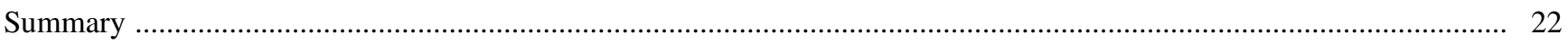

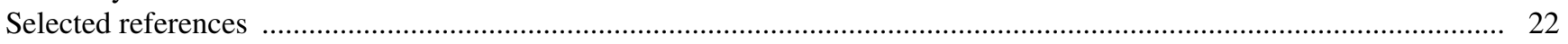

\section{FIGURES}

1. Map showing location and major geographic features of the Beaver Kill basin, in southeastern New York ...... 2

2. Map showing areal distribution of major surficial geologic units and location of geologic sections within the

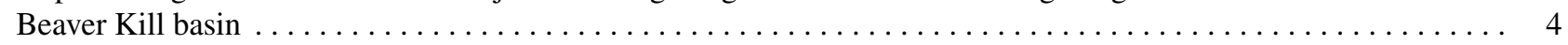

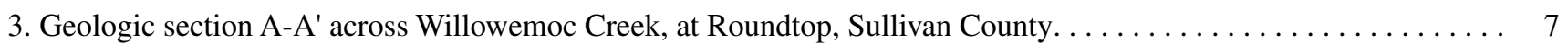

4. Geologic section B-B' across the Beaver Kill valley at Cragie Claire, Sullivan County $\ldots \ldots \ldots \ldots \ldots \ldots \ldots \ldots$

5. Geologic section C-C' across the Beaver Kill valley at Jersey Brook, Sullivan County $\ldots \ldots \ldots \ldots \ldots \ldots \ldots .9$

6. Geologic section D-D' along the East Branch Delaware aqueduct crossing of the Beaver Kill valley at Lewbeach,

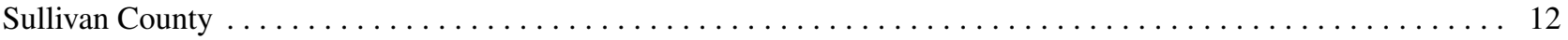

7. Geologic section E-E' along the East Branch Delaware aqueduct crossing of Willowemoc Creek,

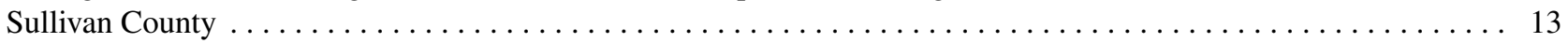

8. Diagram showing conceptual ground-water flow within the Beaver Kill basin $\ldots \ldots \ldots \ldots \ldots \ldots \ldots \ldots \ldots \ldots$

9. Map showing lines of equal of precipitation and runoff, and zones of evapotranspiration within the Beaver

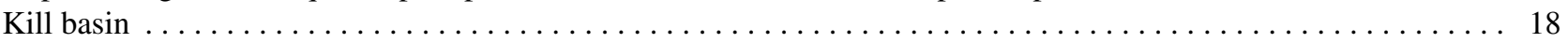

10. Graph showing relations between summer runoff from natural storage and average annual precipitation for

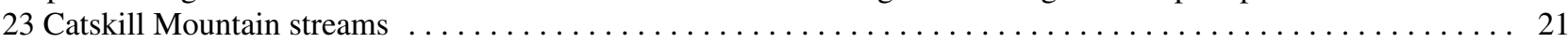

\section{TABLES}

1. Comparison of hydrogeologic characteristics of 13 Delaware River drainage basins within the Catskill Mountains,

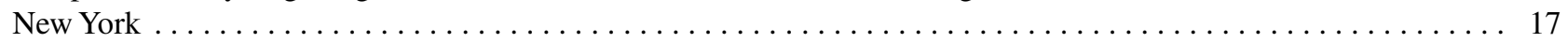




\begin{tabular}{|c|c|c|}
\hline Multiply & By & To obtain \\
\hline \multicolumn{3}{|c|}{ Length } \\
\hline inch (in.) & 2.54 & centimeter \\
\hline foot $(\mathrm{ft})$ & 0.3048 & meter \\
\hline mile (mi) & 1.609 & kilometer \\
\hline foot per mile (ft/mi) & 0.1894 & meter per kilometer \\
\hline \multicolumn{3}{|c|}{ Area } \\
\hline square mile $\left(\mathrm{mi}^{2}\right)$ & 2.590 & square kilometer \\
\hline \multicolumn{3}{|c|}{ Flow rate } \\
\hline cubic foot per second $\left(\mathrm{ft}^{3} / \mathrm{s}\right)$ & 0.02832 & cubic meter per second \\
\hline cubic foot per second $\left(\mathrm{ft}^{3} / \mathrm{s}\right)$ & 28.32 & liter per second \\
\hline gallon per minute (gal/min) & 0.06309 & liter per second \\
\hline gallon per day per square mile $\left[(\mathrm{gal} / \mathrm{d}) / \mathrm{mi}^{2}\right]$ & 0.001461 & cubic meter per day per square kilometer \\
\hline million gallons per day (Mgal/d) & 0.04381 & cubic meter per second \\
\hline million gallons per day (Mgal/d) & 3,785 & cubic meters per day \\
\hline \multicolumn{2}{|l|}{ million gallons per day per square mile } & cubic meter per day per square kilometer \\
\hline gallons per day per square mile $\left[(\mathrm{gal} / \mathrm{d}) / \mathrm{mi}^{2}\right]$ & 0.001462 & cubic meters per day per square kilometer \\
\hline gallon per day per foot $[(\mathrm{gal} / \mathrm{d}) / \mathrm{ft}]$ & 0.0001437 & liter per second per meter \\
\hline \multicolumn{3}{|c|}{ Hydraulic Units } \\
\hline transmissivity, feet squared per day $\left(\mathrm{ft}^{2} / \mathrm{d}\right)$ & 0.0929 & meter squared per day \\
\hline hydraulic conductivity, feet per day (ft/d) & 0.3048 & meter per day \\
\hline \multicolumn{2}{|l|}{ specific capacity, gallons per minute per foot } & liter per second per meter \\
\hline pound per cubic foot $\left(\mathrm{lb} / \mathrm{ft}^{3}\right)$ & 0.01602 & gram per cubic centimeter \\
\hline
\end{tabular}

Sea level: In this report, "sea level" refers to the National Geodetic Vertical Datum of 1929 (NGVD of 1929) - a geodetic datum derived from a general adjustment of the first-order level nets of both the United States and Canada, formerly called Sea Level Datum of 1929. 


\title{
Hydrogeology of the Beaver Kill Basin, in Sullivan, Delaware, and Ulster Counties, New York
}

\author{
by Richard J. Reynolds
}

\section{ABSTRACT}

The hydrogeology of the 299-square-mile Beaver Kill basin in the southwestern Catskill Mountains of southeastern New York is depicted in a surficial geologic map and five geologic sections, and is summarized through an analysis of low-flow statistics for the Beaver Kill and its major tributary, Willowemoc Creek. Surficial geologic data indicate that the most widespread geologic units within the basin are ablation and lodgment till. Large masses of ablation till as much as 450 feet thick were deposited as lateral embankments within the narrow Beaver Kill and Willowemoc Creek valleys and have displaced the modern stream courses by as much as 1,000 feet from the preglacial bedrock-valley axis.

Low-flow statistics for the Beaver Kill and Willowemoc Creeks indicate that the base flows (discharges that are exceeded 90 percent of the time) of these two streams-- 0.36 and 0.39 cubic feet per square mile, respectively--are the highest of 13 Catskill Mountain streams studied. High base flows elsewhere in the glaciated northeastern United States are generally associated with large stratified-drift aquifers, however, stratified drift in these two basins accounts for only about 5 percent and 4.4 percent of their respective surface areas, respectively. The high base flows in these two basins appear to correlate with an equally high percentage of massive sandstone members of the Catskill Formation, which underlies the entire region. Ground-water seepage from these sandstone members may be responsible for the high base flows of these two streams.

\section{INTRODUCTION}

The Beaver Kill basin, which encompasses the drainage areas of the Beaver Kill, Willowemoc Creek, and several smaller tributaries, drains approximately $299 \mathrm{mi}^{2}$ of the rugged southwestern Catskill Mountains in Delaware, Sullivan, and Ulster Counties, N.Y. (fig. 1). The Beaver Kill, and its tributary, Willowemoc Creek, both support a large trout fishery that attracts many anglers each year.

Recent concern among residents, natural-resource managers, and anglers over the health of this trout fishery prompted the Town of Rockland to enter into a cooperative agreement with the U.S.

Geological Survey (USGS) in 1997 to characterize the hydrogeologic system within the Beaver Kill basin. The location and major geographic features of the Beaver Kill basin, are shown in figure 1.

\section{Objectives and Approach}

The primary objectives of this study were to (1) assemble all available surficial geologic maps for the thirteen 7.5-minute quadrangles that encompasses the Beaver Kill basin, (2) reconcile differences among mapped units delineated by various investigators, and (3) produce a 1:48,000-scale digital map of the surficial geology of the basin. All available surficial geologic mapping of the Beaver Kill basin was found to be generally on a reconnaissance level and was limited to those sections of the basin that were within the study areas of Kirkland (1973), Ozvath (1985), and Gubitosa (1980). Copies of some 1:24,000-scale quadrangles showing surficial geologic mapping by these three authors were obtained from the New York 


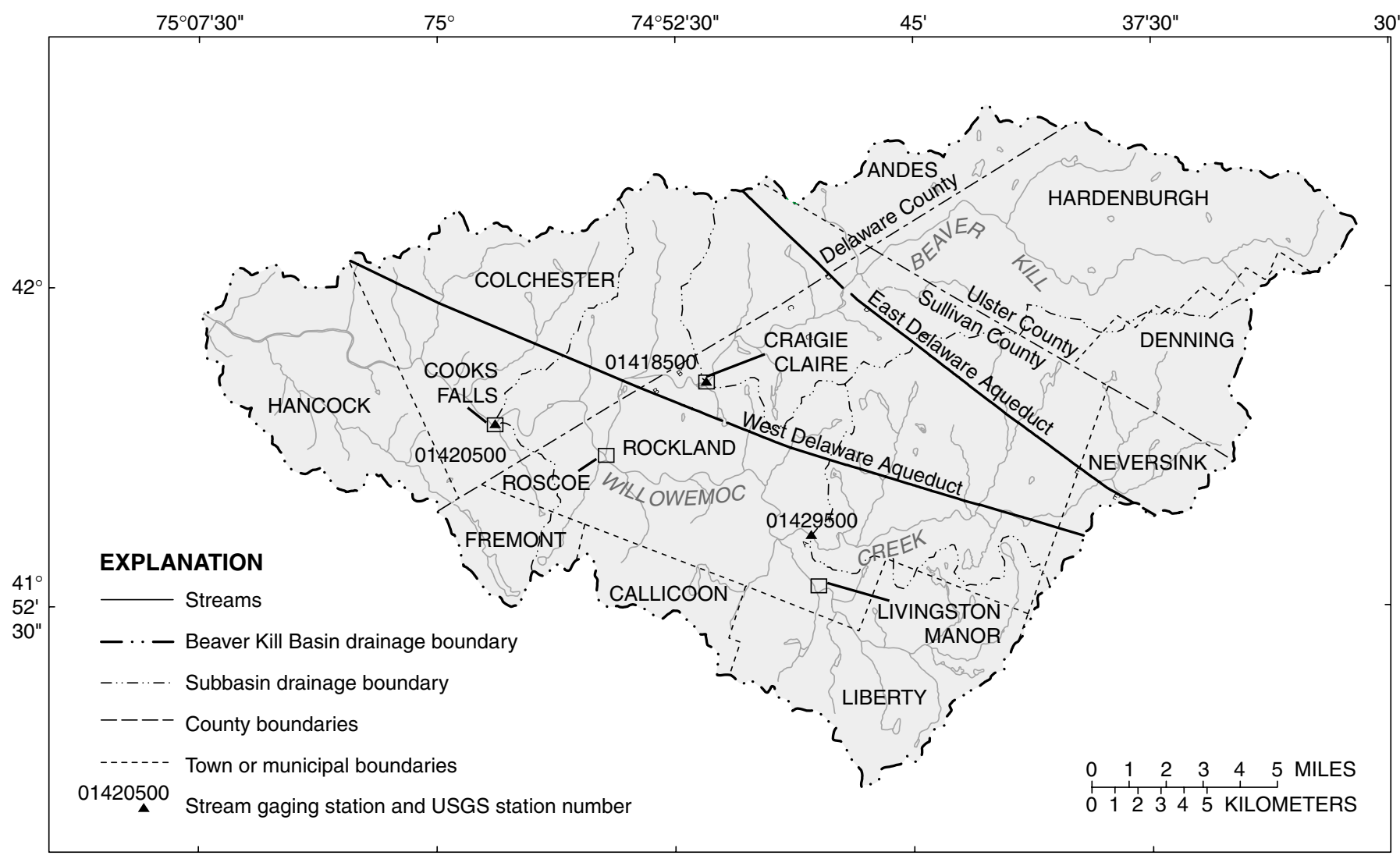

Base from New York State Department of Transportation

1:250,000 series, 1983

Figure 1. Location and major geographic features of the Beaverkill basin in southeastern New York.

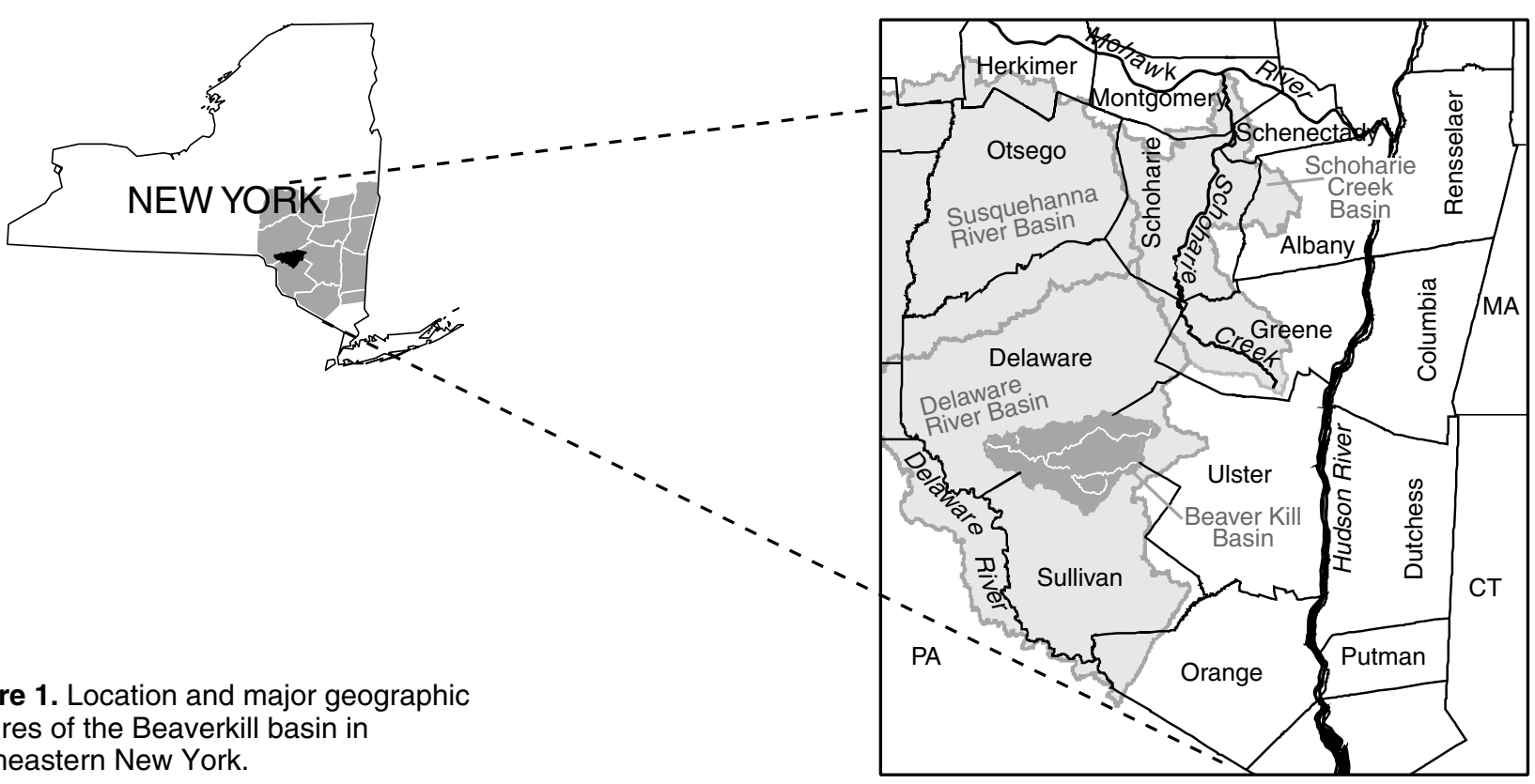


State Geological Survey. Major surficial geologic units in parts of the basin that were not mapped by these investigators, were delineated from 1:62,500-scale reconnaissance field maps produced by Soren as part of two USGS ground-water investigations in Sullivan and Delaware Counties (Soren, 1961, 1963).

\section{Purpose and Scope}

This report (1) describes the major surficial geologic units that occupy the basin, (2) briefly outlines the bedrock geology, (3) compares the hydrogeologic characteristics of the Beaver Kill basin with those of 12 other Delaware river drainage basins, and (4) relates mean annual base flow of the Beaver Kill and Willowemoc Creek to specific hydrogeologic characteristics of the Beaver Kill basin. The report also presents three previously published geologic sections by Fluhr (1948a,b; 1949) and two new ones to illustrate the stratigraphic relationships of major mapped units within the basin.

\section{Previous Studies}

Several previously published works discuss various hydrologic and geologic aspects of the Beaver Kill basin. The surficial geology and deglacial sequences of the western and central Catskill Mountains were first studied in depth by Rich (1935), who studied the western and central Catskills including the eastern upland part of the Beaver Kill and Willowemoc Creek subbasins, and concluded that there was evidence of two distinct drift sheets, which he termed "early" and "late" Wisconsinan. Later investigations of the glacial geology within this basin included doctoral dissertations by Kirkland (1973) and Ozvath (1985), and a Master's thesis by Gubitosa (1980). Of these three studies, only Kirkland's encompassed the entire Beaver Kill basin; Ozvath's study included only the northwesternmost part of the basin, and Gubitosa's study included only the southwesternmost part.

Two water-resource investigations by the USGS in the 1960's, in cooperation with the New York State Department of Conservation, produced reports on the ground-water resources of Sullivan and Delaware Counties (Soren, 1961, 1963), which contain part of the Beaver Kill basin. Geotechnical and engineering studies conducted by the New York City Board of
Water Supply in the mid-to-late 1940's in conjunction with the planned construction of the Delaware Aqueduct System provided several unpublished memoranda reports describing the results of test borings at planned dam sites and aqueduct tunnel crossings (Fluhr, 1948a, b, 1949; Reed and Fluhr, 1948), and two published summary reports (Fluhr, 1953; Fluhr and Terenzio, 1984).

A USGS study of the entire Delaware Basin conducted in the early 1960's by Hely and Olmsted (1963) and Parker and others (1964), and a comparison study of Catskill and Susquehanna River basin streams by Coates (1971) provided streamflow and low-flow data and statistics for both the Beaver Kill and Willowemoc Creek.

\section{GEOLOGY}

The thickness, type and areal extent of surficial geologic units and bedrock units within the Beaver Kill basin are the main factors that determine (1) ground-water availability in the basin, and (2) the amount and distribution of ground water and surface runoff to the Beaver Kill and Willowemoc Creeks.

\section{Surficial Geologic Units}

The major surficial geologic units within the Beaver Kill basin are till, ice-contact stratified drift, outwash, recent alluvium, colluvium, and areas of exposed rock (fig. 2). Till is the most widespread unit within the basin by far and is mapped as six distinct forms: thin till over rock, till, thick till (greater than 5 $\mathrm{ft}$ ), ground moraine, till moraine, and colluvium. Icecontact stratified drift occurs as small, isolated kames, kame terraces, and kame deltas emplaced along the hillsides within the major valleys. Outwash and recent alluvium form a thin, narrow deposit of coarse gravel and sand that floors most of the Beaver Kill and Willowemoc Creek valleys. Colluvium, an unsorted mixture of redeposited till and postglacial sediments, is present along the base of many of the steep valley walls along the Beaver Kill and Willowemoc Creek. Bedrock is commonly exposed along steep hillsides and ridgetops. The origin and distribution of these major units are discussed below. 


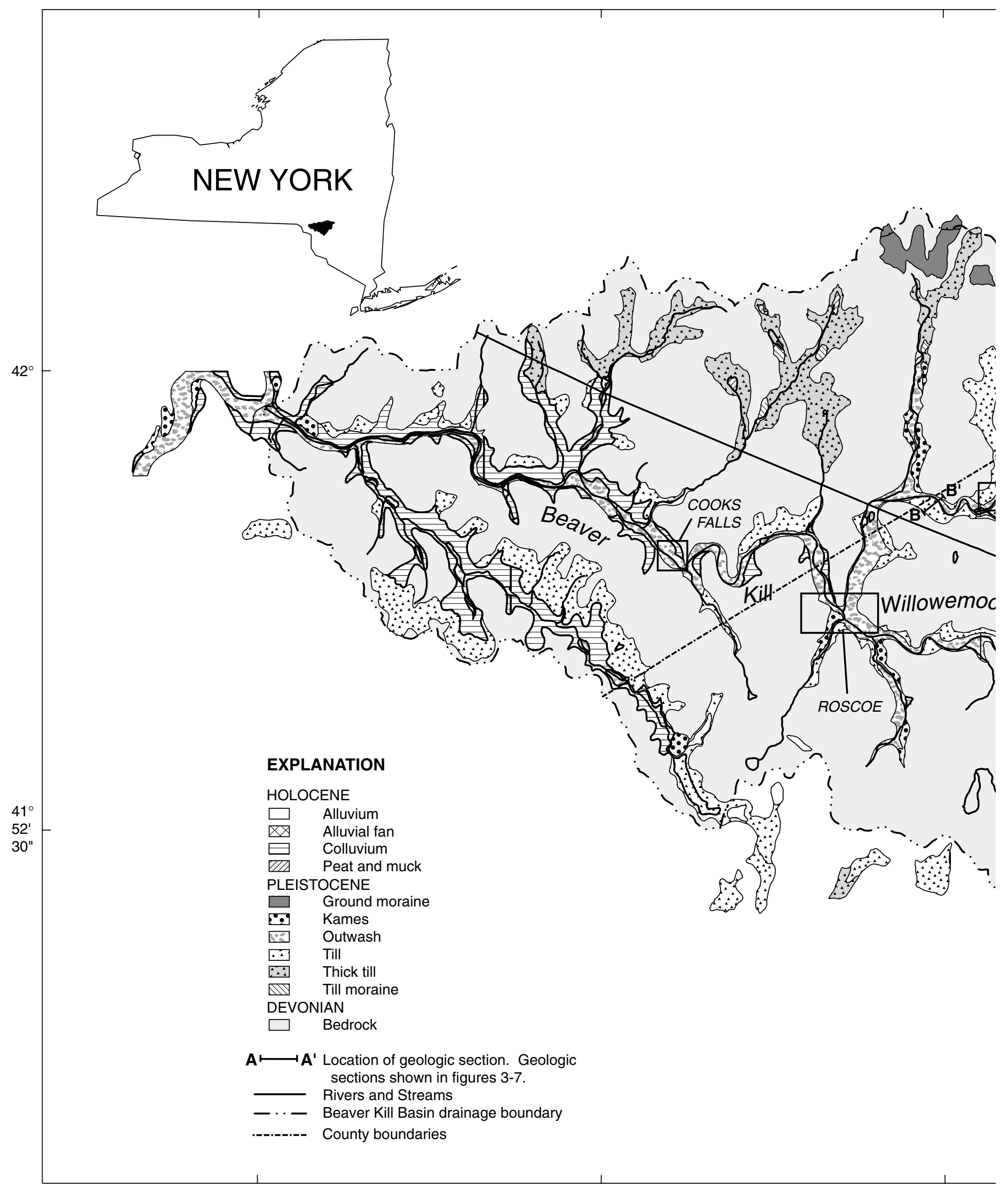

Base from New York State Department of Transportation 1:250,000 series, 1983

Figure 2. Distribution of major surficial geologic units within the Beaver Kill basin, and locations of geologic sections depicted in figures 3 through 7.

4 Hydrogeology of the Beaver Kill Basin, in Sullivan County, Delaware, and Ulster Counties, New York 


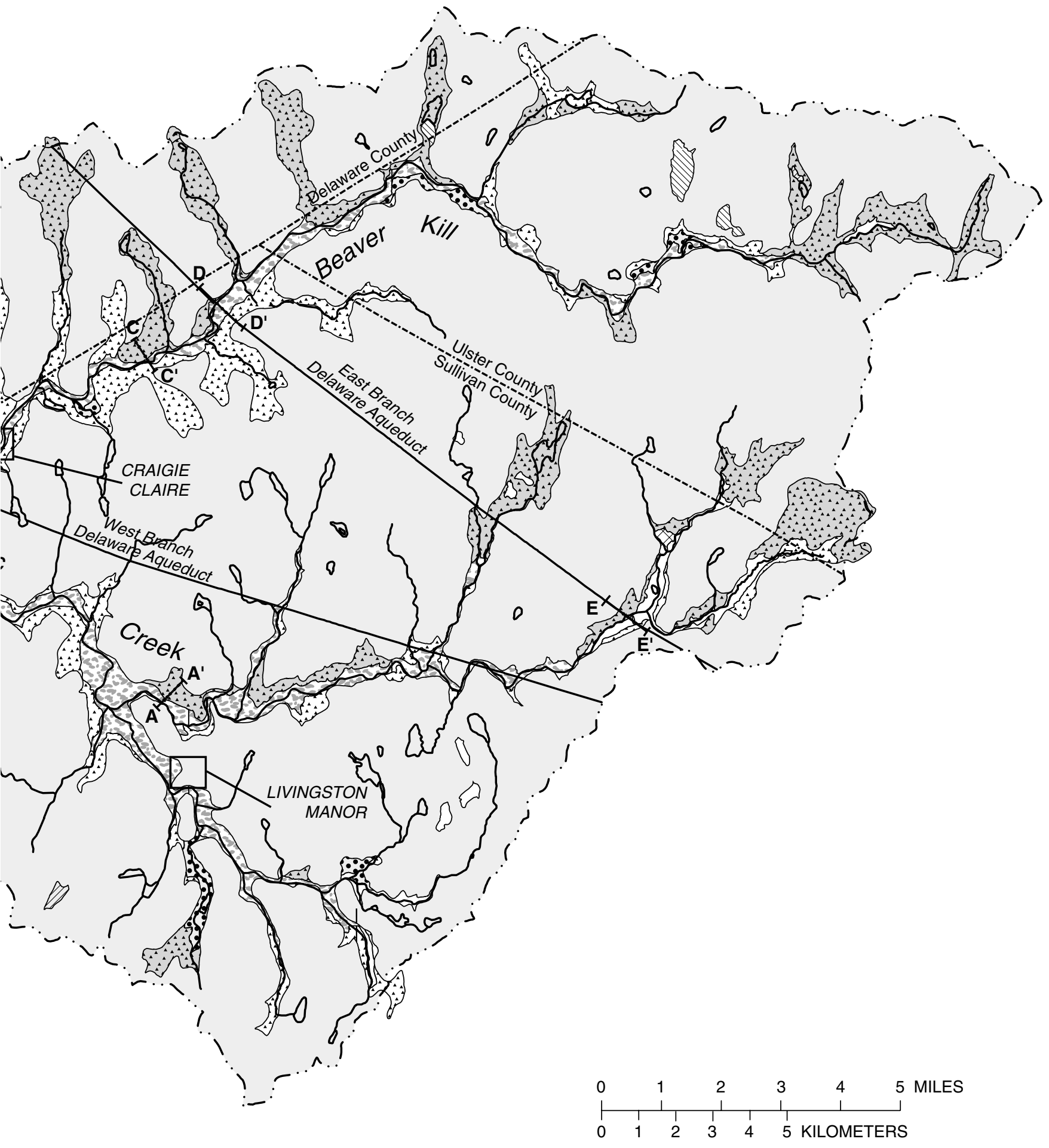

Geology modified by R.J. Reynolds, 1998 from Soren (1961, 1963); Kirkland (1973);Gubitosa (1980), and Ozrath (1985) 
Till

Till is the predominant surficial geologic unit within the Beaver Kill basin and covers approximately 92 percent of the area within the basin. It occurs as (1) thin till over bedrock, (2) ablation and lodgment till in varying thicknesses, (3) areas of thick ground moraine, and (4) till moraine, deposited as distinctive landforms. The wide areal extent of till in the Beaver Kill basin is a direct result of the mode of deglaciation (thinning and melting of glacial ice) that occurred there. Continental glacial ice moving southward over the high northern drainage divide of the Beaver Kill basin became detached from the main ice sheet covering the Catskills and ceased to flow. This detached glacial ice that occupied the main Beaver Kill and Willowemoc valleys then stagnated and melted during what is known as "ice-stagnation retreat." This topographically controlled, massive ice stagnation resulted in the deposition of large amounts of ablation till in the valley bottoms and of lodgment till in high upland tributaries. Ozvath (1985) refers to the ablation till as "valley diamicton" and ascribes its deposition to the resedimentation of supraglacial and englacial debris during the melting of underlying ice. Large masses of ablation till in the western Catskills are commonly associated with, and may interfinger with, ice-contact stratified drift (kame) deposits. This interfingering resulted a wide variability in till composition, and was produced by the multiple depositional processes that occurred during ice ablation, such as resedimentation, meltwater runoff, and slope colluviation (Ozvath, 1985). The ablation till in this basin has been described as a massive, matrixsupported deposit of clasts of sand, silt, and gravel ranging from granule to boulder size. The matrix ranges from loamy silt to silty sand and is reported to be less compacted than adjacent upland ground moraine (Ozvath, 1985).

Thick deposits of ablation till in the western Catskills form a variety of recognizable landforms such as drumlins, morainal loops, ridges, knobs, and lateral embankments. Rich (1935) was the first to recognize such features as ablation till and to ascribe their occurrence as indicative of deposition by active ice margins. Later workers, notably Kirkland (1973) and Ozvath (1985), maintain that these features resulted from the disintegration of stagnant ice within the stream valleys, especially in valleys that are oriented perpendicular to the southwestward direction of continental ice flow. These large ablation till landforms have appreciably altered the courses of the Beaver Kill and Willowemoc Creek, as well as many other streams in the western Catskills. Test borings conducted in the 1940's by the New York City Board of Water Supply as part of geotechnical investigations for the East Branch and West Branch Delaware aqueducts and for several proposed dam sites reveal that large thicknesses of ablation till emplaced against the valley walls (lateral embankments) have displaced the postglacial valley axis as much as $1,000 \mathrm{ft}$ from the preglacial bedrock valley axis. Geologic section A-A' (fig. 3) across shows approximately $750 \mathrm{ft}$ of southwestward axis displacement to in the Willowemoc Creek valley at Roundtop (Fluhr, 1948b). Logs of test borings at this site indicate that nearly all of the valley-fill sediment is till with interbedded lenses of sand and gravel or sand and silt. A maximum till thickness of $360 \mathrm{ft}$ was penetrated by test boring 2 (fig. 3).

Geologic section B-B' (fig. 4) indicates the stratigraphy and valley geometry across the Beaver Kill valley at Craigie Claire to be similar to that in the Willowemoc Creek valley at Roundtop, except that the ablation till here contains more lenses of sand and gravel, and of silt and clay (fig. 4). The thickest section of till penetrated at this site is between test borings 3 and 4, where approximately $350 \mathrm{ft}$ of till and interbedded lacustrine sand and silt was penetrated (Fluhr, 1948a). The lenses of lacustrine silt and sand are the result of small, short-lived glacial lakes that occupied the depressions between the valley wall, previously deposited till, and the disintegrating ice mass. The lenses of sand and gravel are the result of fluvial resedimentation and sorting of till by glacial meltwater. Fluhr called these lenses "modified glacial drift" and, although some individual beds are permeable, none are areally extensive. As at the Roundtop site, the lateral embankment of ablation till here has moved the course of the postglacial Beaver Kill about 1,000 ft north of the bedrock valley axis.

A third example of a thick lateral embankment of ablation till is depicted in geologic section C- $\mathrm{C}^{\prime}$ at a formerly proposed damsite across the Beaver Kill valley at Jersey Brook (fig. 5). This section shows a 480-ft-thick embankment of ablation till emplaced along the north wall of the Beaver Kill valley at this location and which completely fills the original bedrock valley. This lateral embankment has shifted the course of the Beaver Kill about 1,000 ft to the south, such that the stream now flows across a bedrock ledge. 


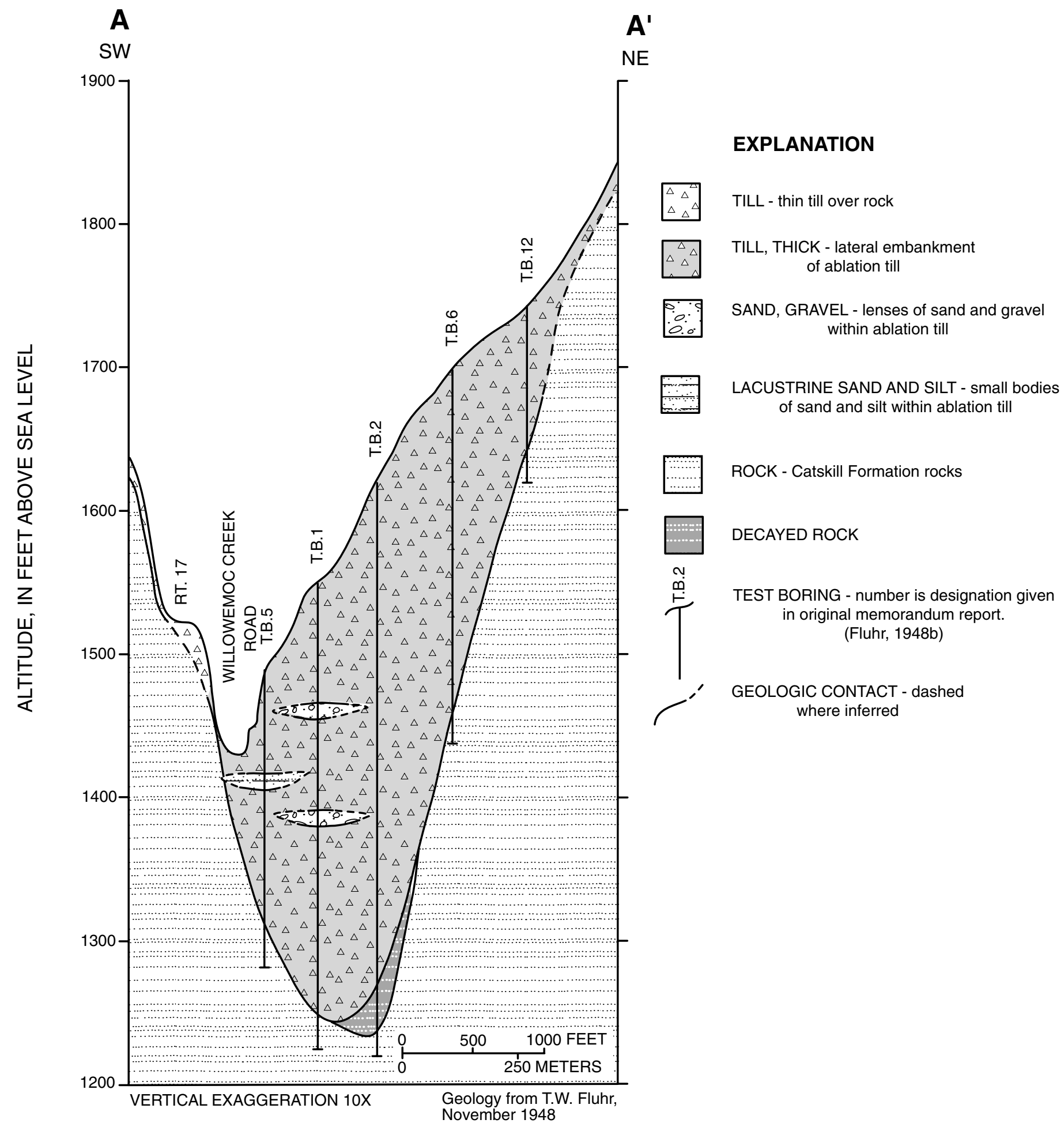

Figure 3. Geologic section A-A' across the Willowemoc Creek valley at Roundtop, N.Y. Trace of section is shown in figure 2 (Modified from Fluhr, 1948b). 


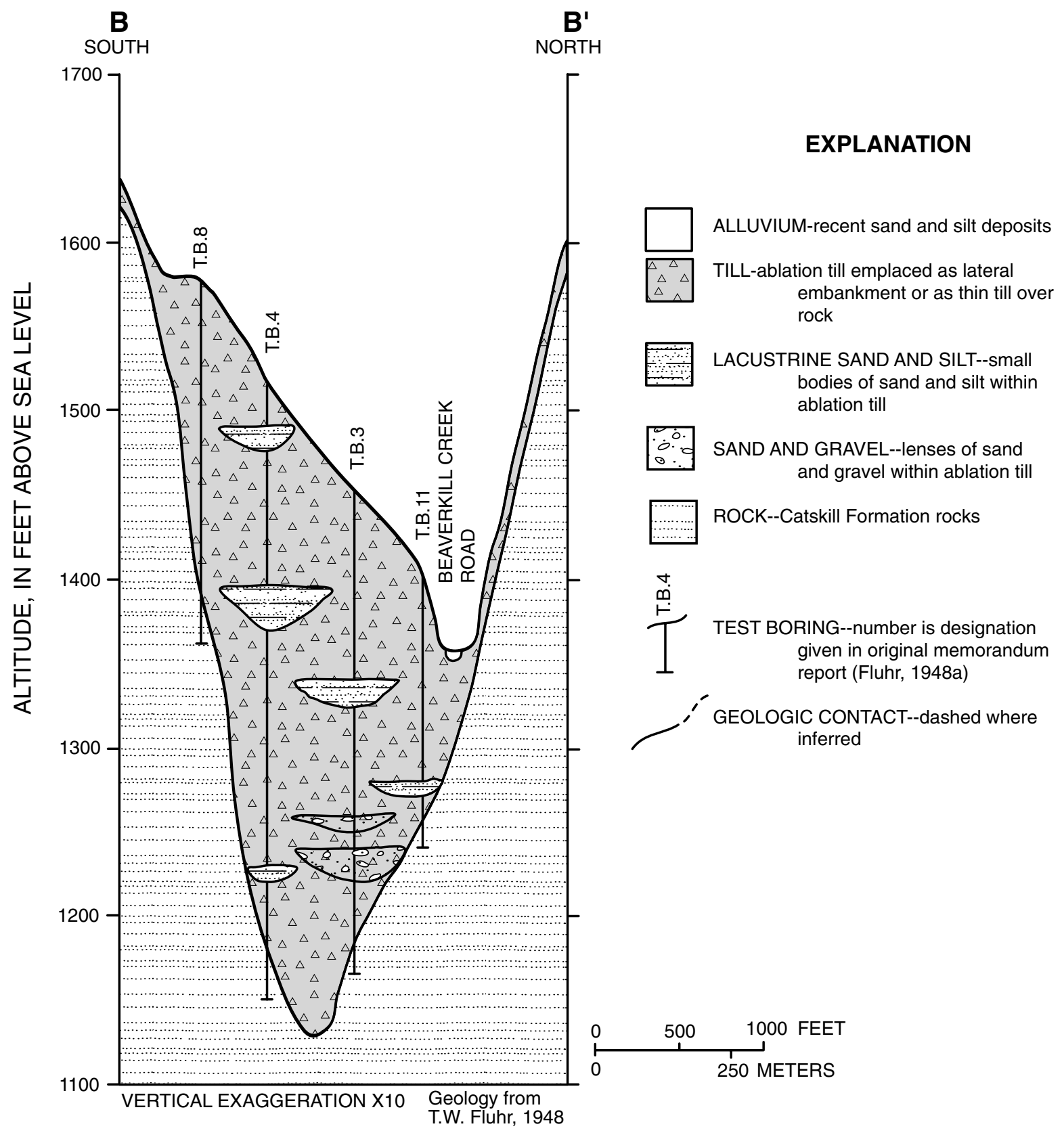

Figure 4. Geologic section B-B across the Beaver Kill valley at Craigie Claire, Sullivan County, N.Y. Trace of section shown in figure 2 (Modified from Fluhr, 1948a). 


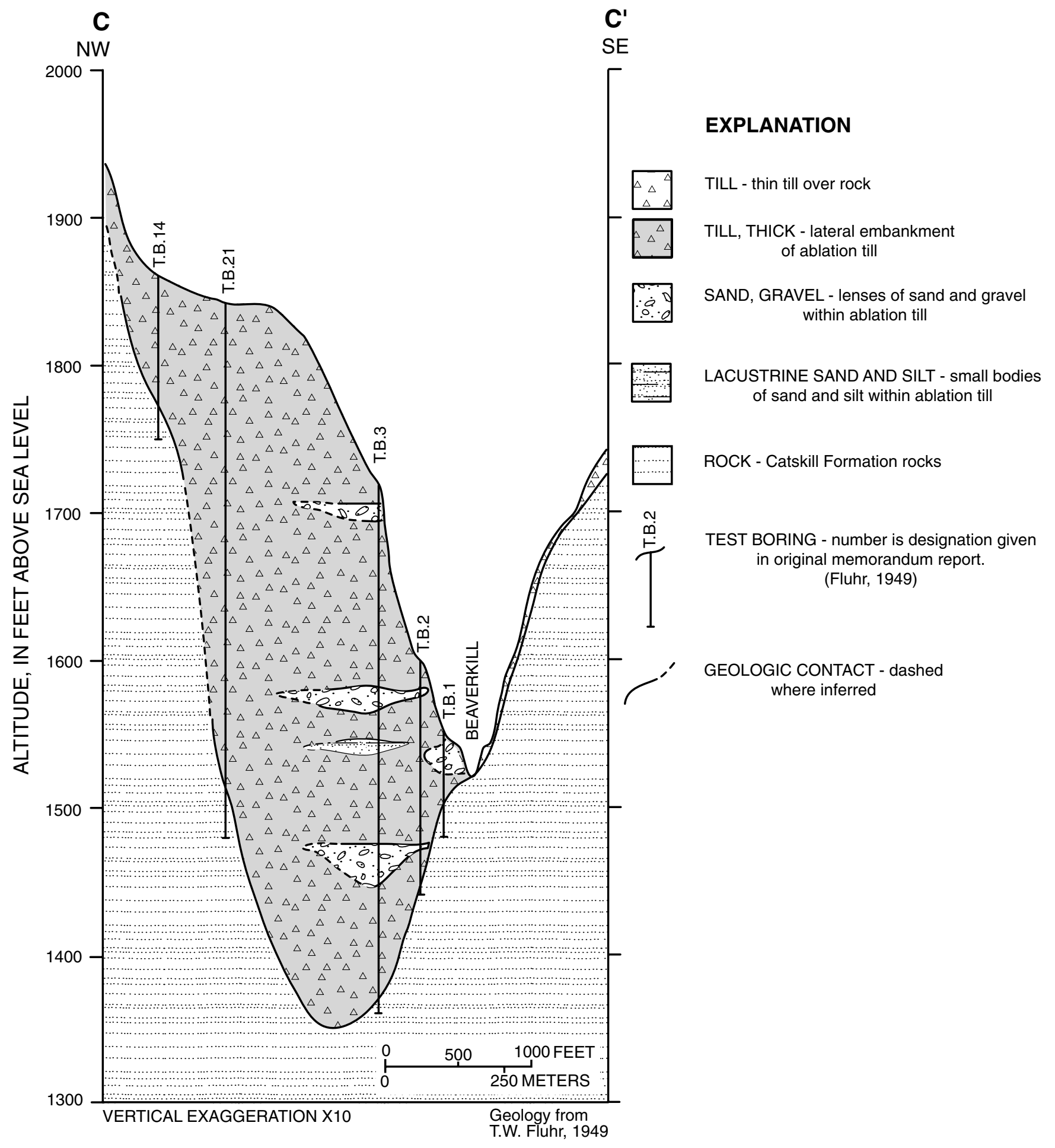

Figure 5. Geologic section C-C across the Beaver Kill valley at Jersey Brook, Sullivan County, N.Y. Trace of section shown in figure 2 (Modified from Fluhr, 1948). 
As at the other two sites, this thick embankment of ablation till incorporates some isolated lenses of sand and gravel and lacustrine silt and clay.

\section{Ground moraine}

Ground moraine is found mostly in the upland areas of the Beaver Kill basin and occurs as a veneer of lodgment till over bedrock. The thickness of this till ranges to $6 \mathrm{ft}$ in most upland areas but can exceed $60 \mathrm{ft}$ in upland hollows and on south-facing slopes (Soren, 1963). Ground moraine in this area is a massive, matrix-supported diamicton with random gravel-sized clasts. The matrix ranges from sandy silt to silty loam with minor amounts of clay and is poorly sorted. Ground moraine was transported and deposited beneath the active glacier and, therefore, is much more compact than ablation till and is difficult to excavate. The thickest accumulations of ground moraine in upland tributary valleys and hollows are the result of several glacial processes: (1) the dropout of subglacial debris as glacial ice moved over lee side depressions,

(2) the meltout of basal debris from active ice, and (3) the meltout of debris from beneath stagnant, basal ice (Ozvath, 1985, p. 54). Ground moraine is absent where bedrock is exposed, such as in cols, notches, and ridges.

\section{Colluvium}

Colluvium constitutes one of the largest surficial geologic units in the Beaver Kill basin and covers about 7.4 percent of the basin (fig. 2). Colluvium commonly overlies valley deposits at the base of steep hillsides. Ozvath (1985) lists three types of colluvium in the western Catskills: (1) remobilized till, (2) talus, and (3) landslides. Remobilized till is present at the base of steep hillsides and forms a hummocky deposit, derived from lodgment till, that has moved downslope under gravity during periglacial conditions. Talus consists of angular, boulder-sized slabs of local bedrock that dislodged from steep valley walls or cliffs and accumulated at the base of the slope. Landslides are associated with the mass downslope movement of earth material, and form convex mounds of colluvium at the base of steep slopes with a corresponding concave depression in the hillside, directly upslope, where the material was removed.

\section{Ice-contact stratified drift}

Geomorphic features within the Beaver Kill basin that are composed of ice-contact stratified drift include kames, kame terraces, kame deltas, and kame moraines. These units (fig. 2) are closely associated with, and commonly interfinger with, adjacent or nearby deposits of ablation till (valley diamicton). Most of these deposits are within the main Beaver Kill and Willowemoc Creek valleys.

Kames are small mounded hills that occupy the valley floor or lower hillslopes and range to $60 \mathrm{ft}$ in height and $800 \mathrm{ft}$ in width. They consist of englacial or supraglacial debris that accumulated during ice melting and typically exhibit a wide range in grain size, sorting, and roundness. The large variability in grain size and sorting reflects the rapid changes in the rates of meltwater flow and sediment release in the glacial environment (Ozvath, 1985).

Kames can be indicative of areas that are favorable for water-supply development where they are largely saturated and hydraulically connected to ice-contact stratified drift at depth or to adjacent or overlying saturated outwash. Surface exposures of kames, even if mostly unsaturated, can be recharge areas for saturated ice-contact deposits at depth.

Kame terraces are large deposits of fluvially deposited ice-contact sediments that once occupied the area between the bedrock valley wall and the ablating ice within the valley. Kame terraces within the Beaver Kill basin can have surface elevations as high as $100 \mathrm{ft}$ above the valley floor and can be as much as $1,000 \mathrm{ft}$ wide and up to a 1/2 mi long. Many kame terraces have been partly eroded by postdepositional slumping or floods. Kame-terrace sediments within the Beaver Kill basin range from silt to cobble-sized gravel and are cross-bedded locally. Ozvath (1985) identified four common sediment facies within kame terraces in the western Catskills, all of which indicate deposition in a braided glacial-stream environment.

Kame deltas are terracelike deposits of stratified sand, gravel, silt, and clay that were deposited by meltwater into a proglacial lake. Ozvath (1985) recognized two forms of kame deltas in the western Catskills--those that flank a valley wall (terraces), and those that extend across the valley. Kame deltas emplaced as flanking terraces were deposited in lakes that developed between the valley wall and the ablating ice tongue, whereas cross-valley kame deltas were deposited in proglacial lakes that developed between the toe of the ice tongue and older downvalley 
deposits. Kame deltas typically have flat-topped terrace surfaces that developed at some depth below a former lake level and consist of three units of sedimentation--topset beds, foreset beds, and bottomset beds. Topset beds were the result of the deposition of coarse sediment in a nearshore, shallowwater environment by meltwater streams; foreset beds were the result of meltwater stream deposition of sediment at the leading edge of a delta advancing into a proglacial lake; and bottomset beds were the result of the deposition of fine-grained sediment in deeper parts of the proglacial lake. Although both foreset and topset beds of kame deltas can contain considerable amounts of coarse sand and gravel, the elevations of these beds are typically above the modern stream grade and, therefore, these deposits are largely unsaturated, and generally do not represent areas of large ground-water potential. They may, however, represent potential ground-water recharge areas for saturated ice-contact deposits at depth.

Kame moraines are ice-contact landforms closely associated with a retreating ice front within a valley and also are known as "outwash heads." Kame moraines generally consist of extremely coarse grained (up to boulder size), well-sorted material which indicates deposition by fast-moving meltwater streams close to the ice. These deposits generally exhibit deformation features from ice shove and can contain inclusions of till. Kame moraines indicate the location of a former ice-margin position within the valley, and their downvalley ends generally grade into outwash deposits. Kame moraines may represent potential areas for ground-water development because they are typically buried beneath later outwash and alluvium and, thus, are mostly saturated.

\section{Outwash and Alluvium}

Outwash consists of well-sorted, coarse-grained sediments deposited by meltwater streams issuing from the ice front. The relatively steep stream gradients within the Beaver Kill basin, coupled with variable meltwater flows and an abundance of coarsegrained sediments, resulted in high-energy braided streams that deposited tens of feet of coarse sand and gravel outwash. This outwash accumulated on the valley floor as the ice receded and formed what is known as a "valley train." Floods commonly reworked and redistributed the outwash and other material during postglacial time, to form a veneer of alluvium over the outwash. Sheets of outwash and alluvium in the major river valleys to the west of the Beaver Kill, such as the East and West Branch Delaware River valleys (fig. 2), are generally less than 2,000 ft wide but can be as much as $1 / 2 \mathrm{mi}$ wide at major valley confluences. Outwash deposits on the valley floors of tributaries such as the Beaver Kill rarely exceed 1,000 $\mathrm{ft}$ in width, however, outwash blankets the main valley of the Beaver Kill and Willowemoc Creek but is absent in the upper reaches of the basin, especially in the small tributary valleys along the northern flank of the Beaver Kill.

The thickness and horizontal continuity of outwash within the Beaver Kill basin is highly variable, as a result of the various deglaciation processes that occurred in the basin. The retreat of stagnant ice, as mentioned earlier, resulted in the deposition of large amounts of ablation till during early stages of deglaciation; thus, most of the valleyfill sediments within the Beaver Kill and Willowemoc Creek valleys are ablation till or a combination of ablation till, ice-contact stratified drift, and finegrained lacustrine sediments. Where outwash is present, it overlies these deposits as a veneer but is as much as $100 \mathrm{ft}$ thick in some places. Test borings that were made in the late 1940's for the New York City Board of Water Supply in conjunction with the eventual construction of the East Branch Delaware Aqueduct revealed wide variability in outwash thickness. Geologic section D-D' (fig. 6), at the East Branch Delaware aqueduct crossing under the Beaver Kill at Lewbeach, shows that the bulk of the valley fill here consists of till and lacustrine sand and silt, with only a 10-ft-thick veneer of outwash and alluvium on the surface. In contrast, geologic section E-E' (fig. 7), at the East Branch Delaware aqueduct crossing under Willowemoc Creek, reveals a narrow deposit of outwash as much as $95 \mathrm{ft}$ thick that fills a narrow valley incised into the till, although most of the valley fill consists of till and fine-grained lacustrine sediment.

\section{Bedrock}

The bedrock that underlies the Beaver Kill basin not only provides ground water to bedrock wells but is a major contributor of ground-water flow (base flow) to the Beaver Kill and Willowemoc Creek. 


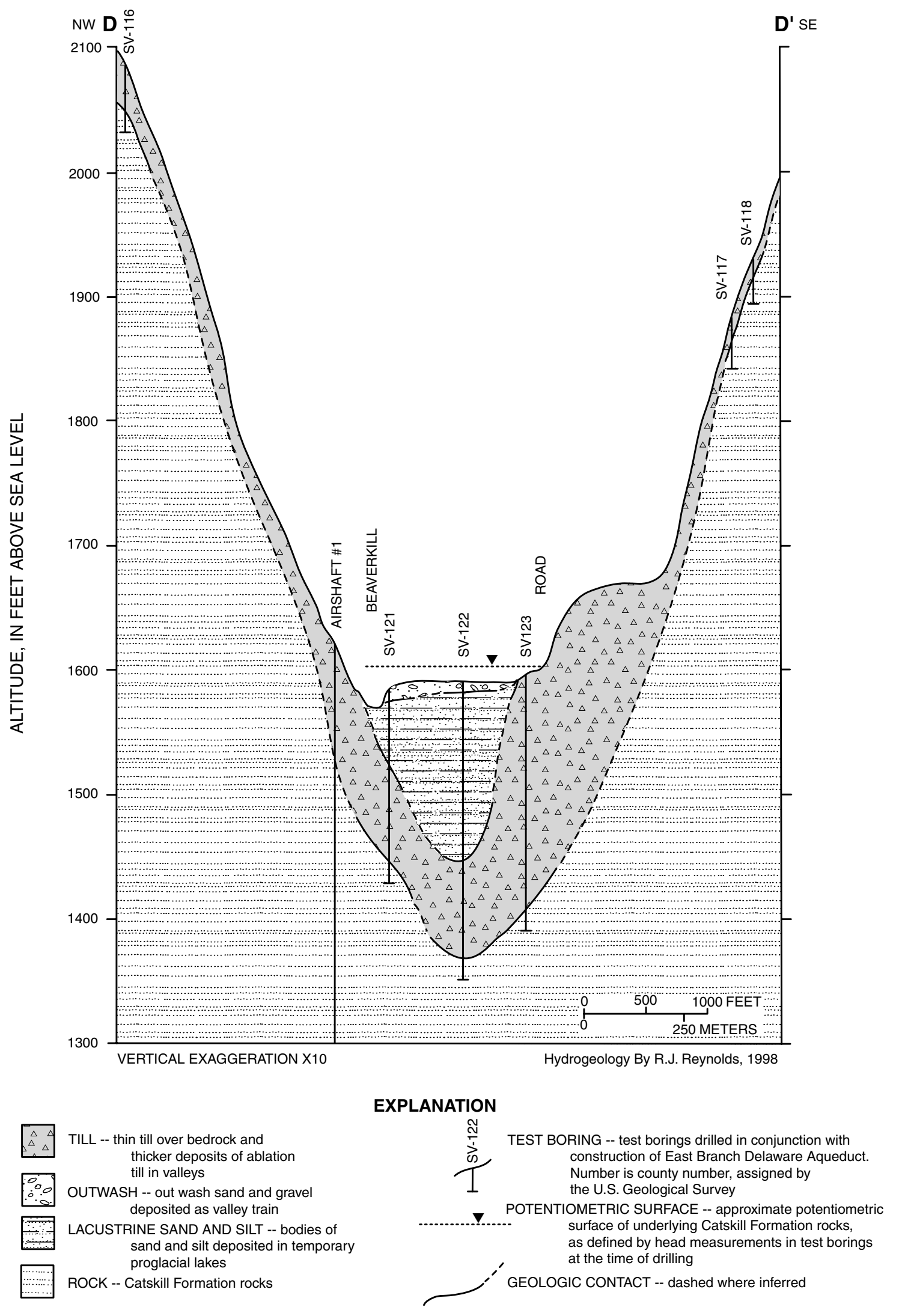

Figure 6. Geologic section D-D' along the East Branch Delaware aqueduct crossing of the Beaver Kill valley at Lewbeach, Sullivan County, N.Y. (Trace of section shown in figure 2.) 


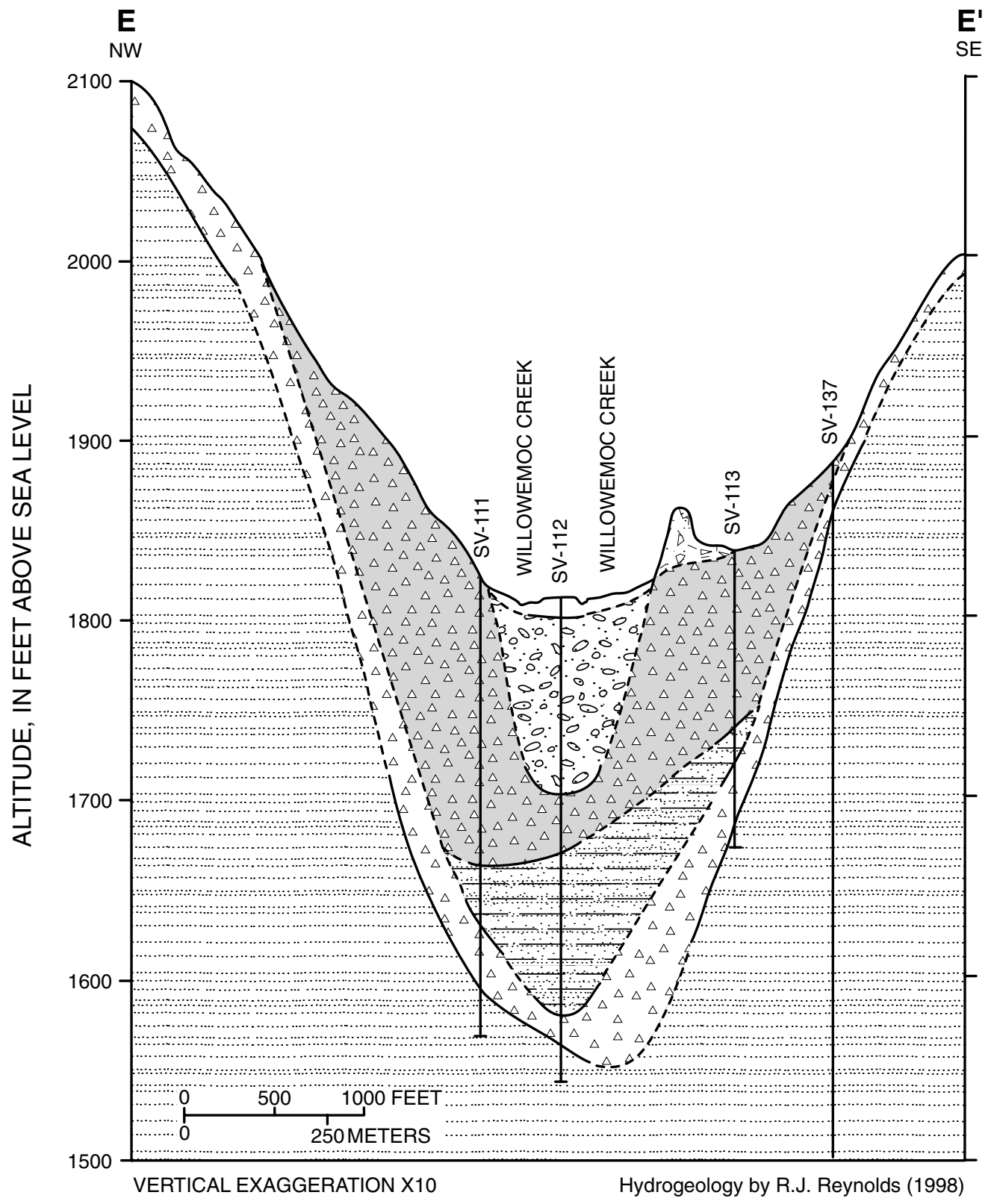

EXPLANATION

ALLUVIUM -- modern and post-glacial flood plain alluvium of silt, clay, sand and gravel

TILL -- thin till over bedrock; includes thicker deposits of ablation till within valleys

TILL, THICK -- lateral embankment of ablation till

TILL MORAINE -- till deposited as distinct morainal landforms

$\because$ OUTWASH -- outwash of sand and gravel deposited as valley train

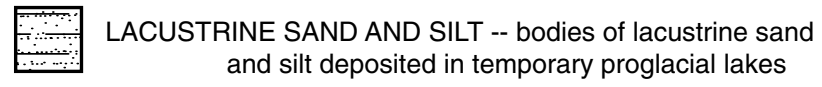

ROCK -- Catskill Formation rocks

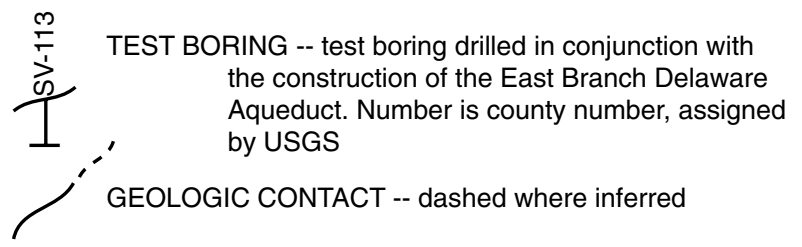

Figure 7. Geologic section E-E' along the East Branch Delaware aqueduct crossing of Willowemoc Creek, Sullivan County, N.Y. (Trace of section shown in figure 2.) 


\section{Stratigraphy}

The entire Catskill Region, including the Beaver Kill basin, is underlain by the Catskill Formation of Upper Devonian age, which is as much as $6,000 \mathrm{ft}$ thick and consists primarily of a sequence of nonmarine sandstones, shales, and conglomerates. Beds within the formation are nearly flat lying and dip slightly to the northwest. The Catskill Mountains were formed by the dissection of a bedrock plateau by streams and glacial erosion. The highest hilltops and ridges, which form the principal drainage divides, are underlain by a siliceous conglomerate that is highly resistant to erosion, the lower hilltops and ridges are capped by sandstone units, which also are highly resistant. The valleys are developed along the strike of less competent siltstones and shales and along fracture zones (Soren, 1961, p. 8).

Fisher and others (1970) and Rickard (1975) have divided the Catskill Formation (or Catskill Facies) in the Beaver Kill basin into three major formations--the Honesdale, Slide Mountain, and Upper Walton Formations--all of which are part of the upper Devonian West Falls Group (Rickard, 1975, pl. 3). Within the Beaver Kill basin, the stratigraphically higher (and younger) Honesdale and Slide Mountain Formations occupy the hilltops and hillsides, and the upper Walton Formation generally underlies the lower slopes and valleys (Fisher and others, 1970). Most of the beds of the Catskill Formation are cut by three intersecting planes of fracture (joints), one of which is parallel to the bedding and two of which are vertical. The two vertical joint sets are roughly perpendicular, which facilitated the quarrying of bedrock from hillsides by glacial ice to produce horizontal surfaces and ledges bounded by nearly vertical cliffs, commonly tens of feet high (Parker and others, 1964). The joint sets also serve to increase the secondary permeability of the rock and, thus, can increase the yield of bedrock wells that intercept one or more joints that transmit ground water. Parker and others (1964) characterize the beds of the Catskill Formation as being poor to moderately good aquifers whose well yields can vary widely within short distances. In general, the sandstone beds are much more permeable than the shale or conglomerate beds, although some sandstone units are so massive and completely cemented (lacking in fractures) that they transmit little water (Parker and others, 1964, p. 82).

\section{Ground Water}

Records of 371 wells drilled into the Catskill Formation within the Appalachian Plateau physiographic province of the Delaware River basin indicate well depths ranging from 5 to $960 \mathrm{ft}$, and yields ranging from 0 to $600 \mathrm{gal} / \mathrm{min}$, with an average yield of $25 \mathrm{gal} / \mathrm{min}$ (Parker and others, 1964). Wells that are completed in the Catskill Formation and are situated on valley floors typically exhibit artesian flow because potentiometric heads are above land surface. Data from exploratory borings made in the 1930's and 1940's along the routes of the East and West Delaware Aqueducts show that several borings in valley floor and lower hillside settings produced artesian flow because the potentiometric surface was more than 10 feet above land surface.

Ground water from the Catskill Formation generally is of excellent quality and is typically used for domestic, industrial, and municipal supplies without treatment. Hardness ranges from very soft to moderately hard, and dissolved solids concentrations are generally low. Iron concentrations are typically low, but can be elevated locally (Parker and others, 1964).

\section{Ground-Water Flow System}

The sequence of permeable sandstone units alternating with less permeable shale units within the Catskill Formation forms a series of stacked aquifers separated by confining units of varying thickness. Ground water within each of the sandstone units can be locally perched near the mountainsides, but is part of a larger saturated zone within each mountain or ridge. Weathering and glacial erosional processes such as scouring, plucking, and glacial unloading, have made exposed rock and rock nearest to the mountainsides typically more jointed and fractured than the unexposed rock type located deep within each mountain or ridge. This jointing increases the secondary permeability in these areas and, in turn, enhances the movement of ground water within these jointed zones, such that a water table is established. The water table within each saturated aquifer unit slopes downward toward its respective discharge point (spring) along the mountainside, as illustrated in figure 8. Thus, the jointed and weathered zone of each bedrock unit that lies immediately beneath the mountainside gives rise to a stepwise pattern of ground-water discharge from the ridgetop to the valley bottom (fig. 8). Horizontal joints and permeable bedding-plane fractures typically form at the contact 


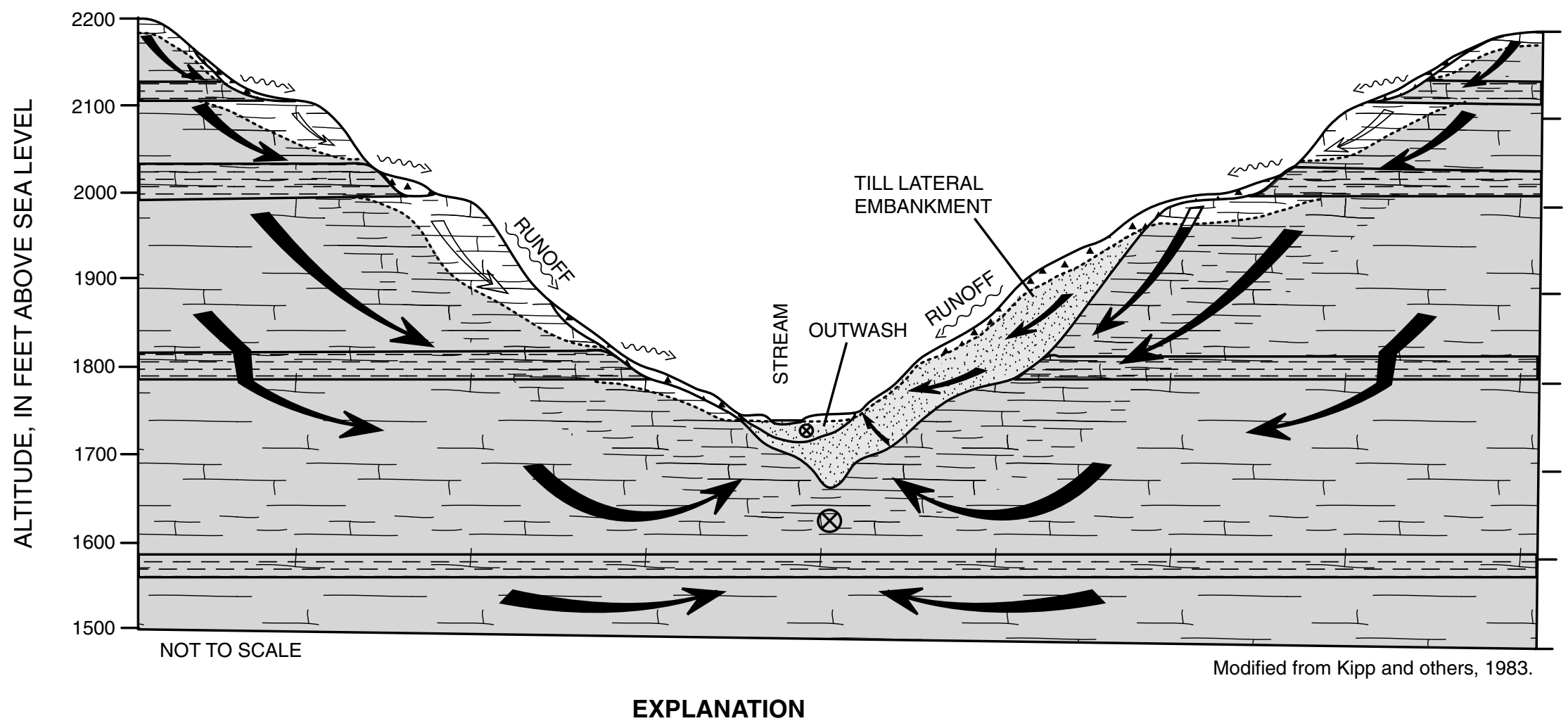

SANDSTONE -- fractured, saturated where shaded

$E=-$ CONFINING BED -- shales

$\because$ TILL -- lateral embankment of ablation till; saturated where shaded

OUTWASH -- valley train outwash and alluvium; saturated where shaded

........... WATER TABLE

ms SPRING DISCHARGE -- contact springs at the base of sandstone members

$\longrightarrow$ GROUND WATER FLOW -- generalized direction of ground water flow within zone of saturation

$\longrightarrow$ UNSATURATED FLOW -- generalized direction of unsaturated flow in fractured bedrock

$\otimes \quad$ DOWN-VALLEY FLOW -- indicated flow into the page (down-valley)

Figure 8. Conceptual ground-water flow within the Beaver Kill Basin, New York. 
between lithologically dissimilar rock units; therefore, ground water within a saturated sandstone member typically discharges along the contact with the underlying shale unit as a contact spring. These springs can be ephemeral features that may flow only during the spring wet season (March and April), but, if the saturated zones above the springs are thick enough, they may flow all year long. These sandstone units also are saturated where they extend into the core of the mountain, but here they are less fractured or jointed, and ground water within them moves mainly as slow, diffuse flow through small intergranular spaces and small, discontinuous fractures and, therefore, probably contributes little to contact springs.

Ground water within saturated sandstone in valley segments that contain thick deposits of ablation till (lateral embankments) occurs generally under confined conditions, with heads typically above land surface. For example, records of two test holes drilled into sandstone and basal till along the proposed route of the East Branch Delaware aqueduct crossing of Beaver Kill at Lewbeach ((SV-122, 123) in section E-E', fig. 6) indicate that artesian flow from a 3-indiameter casing ranged to as much as $18 \mathrm{gal} / \mathrm{min}$, and heads ranged from 12 to $13 \mathrm{ft}$ above the valley floor. The large head difference between the water table in the valley and the potentiometric surface of the confined, fractured sandstone at depth may explain the relatively high base flows of streams in this basin.

\section{HYDROLOGY}

The hydrologic characteristics of 25 drainage basins within the Susquehanna and Delaware River basins were analyzed in a study by Coates (1971), in an effort to relate base-flow discharges to geomorphic, geologic, and hydrologic variables and to identify which variables (1) are most closely correlated with low-flow characteristics of streams and (2) yield the most reliable prediction of low-flow characteristics. Coates' study evaluated and compared 25 drainage basins, each with a drainage area smaller than 400 $\mathrm{mi}^{2} ; 13$ of which are in the western Catskill Mountains, and 12 of which are in the northern Susquehanna River Basin. Although the focus of Coates' 1971 study was to compare the predominantly shale Susquehanna basins with the predominantly sandstone Catskill basins, some of the statistics that Coates presented for the Catskill basins can be used to compare the three Beaver Kill subbasins with the other
10 Catskill basins in his study. Selected hydrogeologic data from the 13 western Catskill basins studied by Coates' (1971) are given in table 1, which treats the Beaver Kill and Willowemoc Creek (1) as two separate basins upstream from their confluence (fig. 1), and (2) as a combined basin downstream from their confluence. Stream-flow gages were historically maintained on the Beaver Kill at Craigie Claire (station 01418500) and on Willowemoc Creek near Livingston Manor (station 01419500) in addition to the currently maintained Beaver Kill at Cooks Falls gage (station 01420500). Station locations are shown in fig. 1.

In addition to Coates' 1971 study, Hely and Olmsted (1963) analyzed data from 123 basins within the Delaware River basin for the period 1921-1950; among these were 23 streams in the Catskill Mountain region, including the Beaver Kill and Willowemoc Creek.

\section{Precipitation, Runoff, and Evapotranspiration}

Of the 13 Catskill basins studied by Coates (1971), the Beaver Kill basin (at Cooks Falls) has the greatest relief--a maximum of $2,727 \mathrm{ft}$. The

Willowemoc Creek and Beaver Kill (at Craigie Claire) subbasins receive the greatest average precipitation of the 13 basins--approximately $52 \mathrm{in} / \mathrm{yr}$ and have, correspondingly, the highest mean annual discharges-2.42 and $2.55\left(\mathrm{ft}^{3} / \mathrm{s}\right) / \mathrm{mi}^{2}$ (table 1). These high discharges result from (1) the large amount of precipitation that falls in these two subbasins, and (2) the large amount of runoff, which is a result of the steep topography and the geology of each basin. A recently published map by Randall (1996) showing lines of equal precipitation, runoff, and evapotranspiration in the glaciated Northeast for 1951-80 indicates the wide range of values for these three hydrologic variables within the Beaver Kill basin (fig. 9).

Mean annual precipitation within the Beaver Kill basin ranges from 42 in. at the lowest elevations (downstream western end of the basin) to 55 in. at the highest elevations (eastern end of the basin). Coates (1971) used an average value of $50.1 \mathrm{in} / \mathrm{yr}$ for the entire Beaver Kill basin, and 52 and $51.8 \mathrm{in} / \mathrm{yr}$ for Willowemoc Creek and for Beaver Kill at Cragie Claire, respectively, based on data available in 1958. These average precipitation values are slightly higher 
Table 1. Hydrogeologic characteristics of 13 Catskill drainage basins within the Delaware River Basin in southeastern New York

$\left[\mathrm{mi}^{2}\right.$, square mile; in., inches; $\mathrm{ft}$, feet; $\left(\mathrm{ft}^{3} / \mathrm{s}\right) / \mathrm{mi}^{2}$, cubic feet per second per square mile; Q90, flow at 90 percent duration. Data from Coates, 1971 . Locations are shown in fig. 2. $\underline{\text { Streams within the Beaver Kill basin shown in boldface.] }}$

\begin{tabular}{|c|c|c|c|c|c|c|c|c|c|c|c|}
\hline \multirow[b]{2}{*}{ Basin } & \multirow[b]{2}{*}{$\begin{array}{l}\text { Basin } \\
\text { area } \\
\left(\mathrm{mi}^{2}\right)\end{array}$} & \multirow[b]{2}{*}{$\begin{array}{l}\text { Max. } \\
\text { basin } \\
\text { relief } \\
(\mathrm{ft})\end{array}$} & \multirow[b]{2}{*}{$\begin{array}{l}\text { Mean } \\
\text { annual } \\
\text { precip. } \\
\text { (in.) }\end{array}$} & \multirow[b]{2}{*}{$\begin{array}{c}\text { Mean } \\
\text { annual } \\
\text { discharge } \\
\left.\left[\left(\mathrm{ft}^{3} / \mathrm{s}\right) / \mathrm{mi}^{2}\right)\right]\end{array}$} & \multicolumn{2}{|c|}{ Flow duration $\left(Q_{90}\right) \dagger$} & \multicolumn{2}{|c|}{ Baseflow recession (days) } & \multirow[b]{2}{*}{$\begin{array}{l}\text { Area of } \\
\text { stratified drift } \\
\text { (percent of } \\
\text { basin) }\end{array}$} & \multirow[b]{2}{*}{$\begin{array}{l}\text { Sandstone } \\
\text { index } \\
\text { (percent) }\end{array}$} & \multirow[b]{2}{*}{$\begin{array}{l}\text { Massiveness } \\
\text { index }^{b}\end{array}$} \\
\hline & & & & & $\begin{array}{l}\text { Percent of } \\
\text { mean } \\
\text { annual } \\
\text { discharge }\end{array}$ & $\begin{array}{c}\text { Normalized } \\
\text { to } \\
\text { basin size } \\
\left.\left[\left(\mathrm{ft}^{3} / \mathrm{s}\right) / \mathrm{mi}^{2}\right)\right]\end{array}$ & $\begin{array}{l}\text { To } 10 \text { percent } \\
\text { of mean } \\
\text { annual } \\
\text { discharge }\end{array}$ & $\begin{array}{l}\text { Normalized to } \\
\text { decline from } \\
1.0 \text { to } 0.1 \\
\left(\mathrm{ft}^{3} / \mathrm{s}\right) / \mathrm{mi}^{2}\end{array}$ & & & \\
\hline Terry Clove & 14.1 & 1290 & 44.0 & 1.88 & 10.0 & .188 & 13.5 & 16.5 & 4.3 & 79 & 73 \\
\hline Mill Brook & 25.0 & 2420 & 48.8 & 2.27 & 12.0 & .272 & 26.5 & 36.1 & 2.9 & 91 & 88 \\
\hline Coles Cloves & 28.0 & 1460 & 44.0 & 2.03 & 10.0 & .203 & 17.7 & 21.0 & 5.7 & 79 & 73 \\
\hline Tremper Kill & 33.0 & 2045 & 43.7 & 1.88 & 10.0 & .188 & 13.2 & 25.2 & 5.5 & 88 & 79 \\
\hline Platte Kill & 34.7 & 2055 & 43.0 & 1.82 & 9.0 & .164 & 17.7 & 18.5 & 4.5 & 78 & 71 \\
\hline Trout Creek & 49.5 & 1280 & 43.4 & 1.83 & 11.0 & .201 & 22.5 & 29.7 & 7.6 & 78 & 68 \\
\hline Little Delaware River & 49.8 & 1965 & 42.7 & 1.81 & 7.8 & .141 & 22.7 & 28.0 & 3.6 & 64 & 51 \\
\hline $\begin{array}{l}\text { *Willowemoc Creek near } \\
\text { Livingston Manor }\end{array}$ & 63 & 1960 & 52.0 & 2.42 & 16.0 & .387 & 22.1 & 32.0 & 4.4 & 91 & 88 \\
\hline Oquaga Creek & 66 & 1040 & 43.0 & 1.78 & 8.5 & .151 & 17.5 & 22.9 & 5.2 & 84 & 72 \\
\hline $\begin{array}{l}\text { Beaver Kill at } \\
\text { Craigie Claire }\end{array}$ & 82 & 2495 & 51.8 & 2.55 & 14.0 & .357 & 30.3 & 37.6 & 5.0 & 98 & 96 \\
\hline W. Branch Delaware River & 142 & 1835 & 41.5 & 1.70 & 8.5 & .145 & 27.5 & 33.0 & 12.2 & 64 & 53 \\
\hline E. Branch Delaware River & 163 & 2595 & 44.0 & 1.89 & 10.0 & .189 & 27.1 & 34.7 & 5.0 & 78 & 70 \\
\hline \multicolumn{12}{|l|}{ *Beaver Kill at Cooks } \\
\hline Falls & 241 & 2727 & 50.1 & 2.34 & 16.0 & .374 & 31.5 & 36.7 & 6.0 & 89 & 82 \\
\hline Mean & 76.5 & 1930 & 45.5 & 2.01 & 11.0 & .228 & 23.1 & 28.6 & 5.5 & 81 & 74 \\
\hline
\end{tabular}

a) Sandstone index - the average percentage of sandstone found within measured stratigraphic sections with each basin (Coates, 1971).

b) Massiveness index - the percentage of rock units in observable outcrops that exhibit joint-free exposures of greater than 1-ft in thickness (Coates, 1971).

* Includes Willowemoc Creek drainage. Beaver Kill and Willowemoc Creek are treated as separate basins above their confluence at Roscoe

and as a combined basin downstream from their confluence.

$\dagger \mathrm{Q}_{90}$ - the stream discharge that is exceeded 90 percent of the time. 


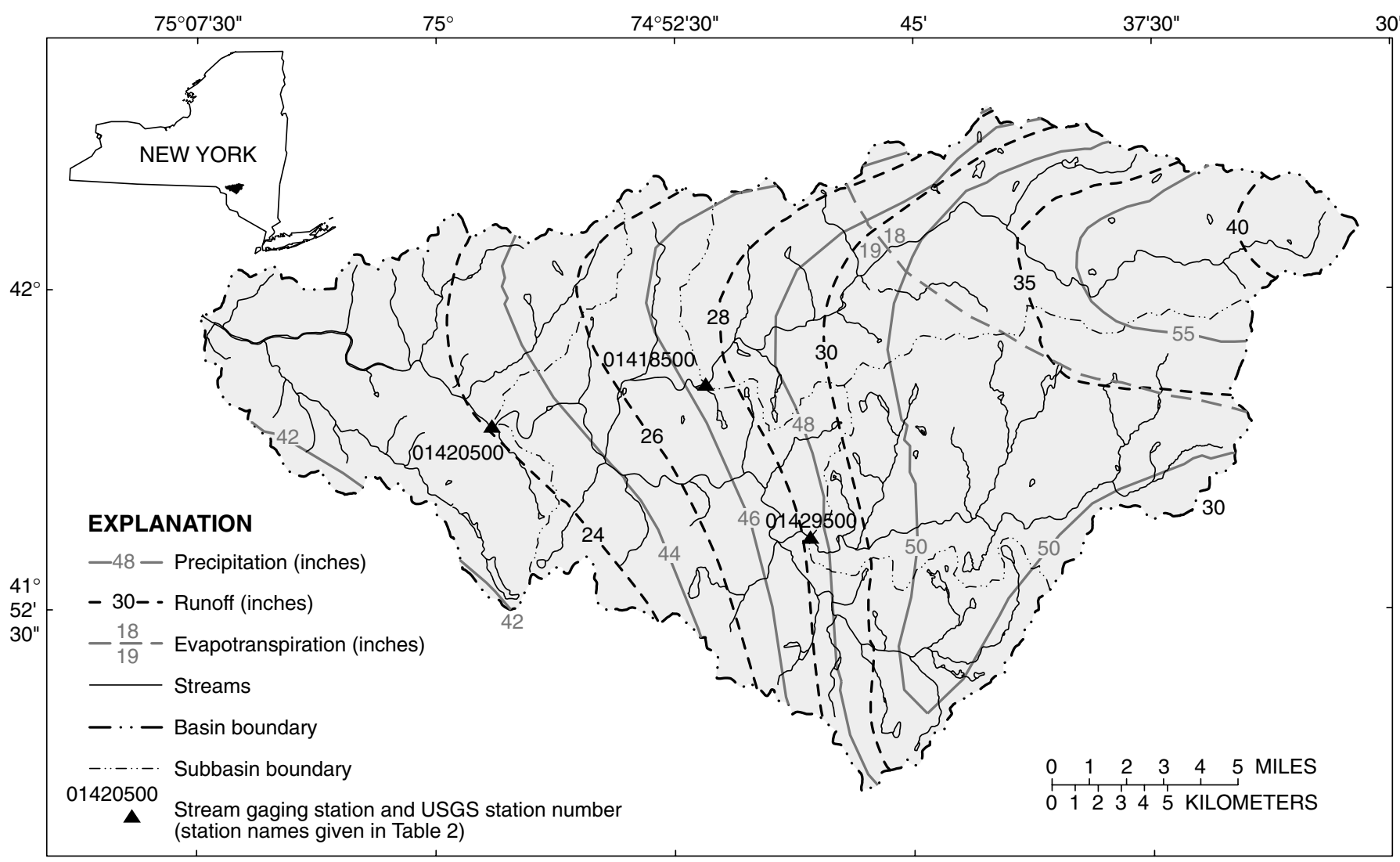

Base from New York State Department of Transportation

1:250,000 series, 1983

Figure 9. Precipitation, runoff, and zones of evapotranspiration within the Beaver Kill basin, New York (Modified from Randall, 1996).

than those indicated by Randall (1996), but are uniformly so and, thus, are suitable for purposes of basin comparison.

Runoff increases from less than 24 in/yr at the western end of the Beaver Kill basin to $40 \mathrm{in} / \mathrm{yr}$ at the extreme eastern end (Fig. 9). This increase corresponds to the general eastward increase in elevation and relief within the Beaver Kill basin. The maximum basin relief, for example, increases from 1,960 ft in the Willowemoc Creek basin (station 01419500) to $2,495 \mathrm{ft}$ in the Beaver Kill subbasin to the north (station 01418500), and to $2,727 \mathrm{ft}$ in the entire Beaver Kill basin (station 01420500).

Hely and Olmsted (1963) calculated average annual runoff for the 123 basins in the Delaware River Basin for the period 1921-1950; their results indicated that the Beaver Kill and Willowemoc Creek subbasins had two of the highest values of average annual runoff-33.7 and $32.9 \mathrm{in} / \mathrm{yr}$, respectively. Evapotranspiration rates within the Beaver Kill basin were calculated by Randall (1996) to range from 19 in. over the western two-thirds of the basin to $18 \mathrm{in.}$ in the eastern third.

\section{Sources of Stream Base Flow}

Several of the low-flow statistics listed in table 1 indicate that the Beaver Kill and Willowemoc Creek have, in proportion to their size, the highest base flows per square mile of the 13 Catskill basins studied by Coates (1971). The discharge that is exceeded 90 percent of the time $\left(\mathrm{Q}_{90}\right)$ is a commonly used measure of base flow. Values of $\mathrm{Q}_{90}$ for the 13 Catskill basins are shown in table 1 in two formats--first as a percentage of mean annual discharge, then as normalized to basin size and expressed as cubic feet per second per square mile. The $\mathrm{Q}_{90}$ for Willowemoc Creek is 16 percent of the mean annual discharge, and the $\mathrm{Q}_{90}$ for the Beaver Kill subbasin is 14 percent; similarly, the $\mathrm{Q}_{90}$ normalized to basin size is 
equivalent to $0.39\left(\mathrm{ft}^{3} / \mathrm{s}\right) / \mathrm{mi}^{2}$ in the Willowemoc basin and $0.36\left(\mathrm{ft}^{3} / \mathrm{s}\right) / \mathrm{mi}^{2}$ in the Beaver Kill subbasin. These relatively high base-flow values indicate that these basins contain a large amount of ground water in storage, presumably in saturated stratified drift along the valley floor. Another statistic that implies large ground water storage within a given basin is the duration of base-flow recession. The Beaver Kill at Cooks Falls (station 01420500) has an average baseflow recession period of 31.5 days (before declining to 10 percent of the mean annual discharge), which is the highest of all 13 basins studied by Coates (1971). A long base-flow recession generally indicates that ground water is supplying the base flow during long precipitation-free periods. Coates (1971) delineated the percentage of land area occupied by stratified drift within each basin and found that stratified drift comprises only 5 percent of the Beaver Kill subbasin above Roscoe, 4.4 percent of the Willowemoc basin, and 6 percent of the Beaver Kill basin above Cooks Falls. The other 10 Catskill basins listed in table 1 contain higher percentages of stratified drift, yet produce smaller sustained base flows than the Willowemoc and Beaver Kill subbasins. Therefore, other hydrogeologic units within the Beaver Kill and Willowemoc basins must be the source of the relatively large contribution of ground water, under base flow conditions, to these two streams.

A possible source may be the bedrock that underlies both basins. Bedrock in the Catskills consists of sandstone, shale, and siltstone, of which sandstone is the most permeable because it contains large, extensive joints. Coates (1971) developed two indices that describe the amount of sandstone present, and the degree of jointing within the sandstone, for each of the 13 Catskill basins he studied (table 1). His "sandstone index" is the average percentage of sandstone found within measured stratigraphic sections within each basin, while the "massiveness index" is a measure of sandstone competency and fabric and is used to quantify the percentage of rock units in observable outcrops with joint-free exposures greater than 1-ft in thickness. Coates observed that joints in the sandstone of the Catskill Mountains are larger and less numerous, but more continuous, than those in the shale bedrock of the Susquehanna River basin to the west (fig. 1) and that most of the sandstone within the 13 Catskill basins studied is massive and, therefore, would tend to have large, continuous joints that could serve to transmit ground water. Of the 13 Catskill basins studied by
Coates, the Beaver Kill and Willowemoc Creek subbasins have the highest sandstone indices--98 percent for the Beaver Kill and 91 percent for the Willowemoc, and two of the highest massiveness indices--96 percent for the Beaver Kill subbasin and 88 percent for Willowemoc Creek (table 1).

Coates performed regression analysis of values for these two indices against 90-percent flow duration $\left(\mathrm{Q}_{90}\right)$, expressed (1) as a percentage of mean annual discharge, and (2) adjusted to $1\left(\mathrm{ft}^{3} / \mathrm{s}\right) / \mathrm{mi}^{2}$, to test whether these two indices are related to certain lowflow statistics for each of the 13 Catskill basins. The results for all 13 Catskill basins indicated a moderately good correlation $\left(r^{2}=0.76\right)$ between the sandstone index and $\mathrm{Q}_{90}$, and a similar correlation $\left(\mathrm{r}^{2}=0.79\right)$ between the "massiveness index" and $\mathrm{Q}_{90}$ (Coates, 1971, table 6). Similarly, his regression analysis of precipitation against $\mathrm{Q}_{90}$ for the 13 Catskill basins shows a high correlation $\left(\mathrm{r}^{2}=0.90\right)$ for $\mathrm{Q}_{90}$ expressed as a percentage of mean annual discharge, and a slightly higher correlation $\left(\mathrm{r}^{2}=0.95\right)$ for $\mathrm{Q}_{90}$ adjusted to $1 \mathrm{ft}^{3} / \mathrm{s} / \mathrm{mi}^{2}$. Coates' regression analyses of $\mathrm{Q}_{90}$ against other geomorphologic factors for the 13 Catskill basins showed relatively poor correlation coefficients, however. For example, a regression of $\mathrm{Q}_{90}$ against maximum basin relief yielded an $\mathrm{r}^{2}$ of only 0.49 for $\mathrm{Q}_{90}$ expressed as a percentage of mean annual discharge, and an $\mathrm{r}^{2}$ of 0.53 for $\mathrm{Q}_{90}$ adjusted to $1\left(\mathrm{ft}^{3} / \mathrm{s}\right) / \mathrm{mi}^{2}$. The results of Coates' study seem to indicate that the sustained high base flows in the Beaver Kill and Willowemoc subbasins are the result of considerable ground-water seepage, presumably from the jointed sandstone aquifer.

The thick till that covers most of the upland parts of the Beaver Kill and Willowemoc subbasins might seem to be a potential source of base flow, but recent studies in New York and New England have shown that ground-water flow from thick till deposits does not significantly increase the base flow of streams in glaciated basins. Randall and Johnson (1987) present four low-flow equations, each one developed from a separate low-flow study in the glaciated northeast, to estimate the average minimum 7-day low flow, known as the 7Q10. All four equations include independent variables that account for the area of stratified drift, the area of till, the mean runoff or the mean altitude, and the area occupied by wetlands (Randall and Johnson, 1988, table 1). In each of these studies, the regression coefficient for the area covered by stratified drift was from 9 to 25 times larger than 
that for the area covered by till. Regression coefficients for stratified drift ranged from 0.46 to 2.16, whereas those for till ranged from 0.05 to 0.10 . These coefficients indicate that the area of till within a basin has only minor effect on the contribution of ground water to stream base flow.

A similar study by Wandle and Randall (1994) of the effects of surficial geology, lakes, swamps, and annual water availability on low flows of streams in central New England reached similar conclusions regarding the effect of till and stratified drift on stream base flow. The regression equations developed in that study to estimate 7Q10 for both high-relief and lowrelief areas of central New England indicated that ground-water discharge from coarse stratified drift is 4 to 8 times greater than the discharge from till. These results provide additional evidence to suggest that the high sustained base flows within the Beaver Kill and Willowemoc Creek subbasins may be the result of ground-water discharge from the underlying fractured and jointed sandstone, not from the large areas of thick till that blanket the uplands of both basins.

\section{Sub-basin runoff}

A study of the entire Delaware River Basin by Hely and Olmsted (1963) presents runoff statistics for each of 23 Catskill Mountain streams under two separate summer low-flow conditions:

1. The amount of base flow from ground-water storage $\left(R_{a}\right)$ for 30 days following a discharge equal to mean annual discharge (expressed in inches), and

2. The amount of base flow from ground-water storage $\left(\mathrm{R}_{1.0}\right)$ for 30 days following a discharge equal to $\left(1.0 \mathrm{ft}^{3} / \mathrm{s}\right) / \mathrm{mi}^{2}$. This discharge, for any of the streams studied, would be the numerical equivalent of the drainage area as measured at the gaging station, in cubic feet per second and expressed in inches.

Hely and Olmsted plotted both values of base flow against the respective mean annual precipitation for each of the 23 Catskill streams (fig. 10). Best-fit regression lines through both sets of data indicate that base flow increases as mean annual precipitation increases, but at a much greater rate when calculated from $\mathrm{R}_{\mathrm{a}}$ data than from $\mathrm{R}_{1.0}$ data. The base-flow value $\mathrm{R}_{\mathrm{a}}$ increases rapidly as mean annual precipitation increases because high mean precipitation produces high mean runoff; therefore, the 30-day segment of the recession curve used to calculate the value $\left(R_{a}\right)$ will be located relatively high on the recession curve.
Therefore, the $\mathrm{R}_{\mathrm{a}}$ values for each basin are a weaker indication of ground-water contributions during dry conditions than are $\mathrm{R}_{1.0}$ values. If the 23 basins have similar geologic characteristics, values of $\mathrm{R}_{1.0}$ for these streams should not vary with precipitation because areal variations in mean annual precipitation are independent of the physical characteristics of a given basin. The $\mathrm{R}_{1.0}$ data in figure 10 show a significant upward trend, however, which indicates that $\mathrm{R}_{1.0}$ does increase with increasing mean annual precipitation. Hely and Olmsted (1963) attributed this upward slope to local variations in geology, topography, and(or) ground-water evapotranspiration, and plotted winter values of $\mathrm{R}_{1.0}$ for these streams against mean annual precipitation. The resulting data showed essentially the same slope, suggesting that the relationship does not involve ground-water evapotranspiration, which is absent in winter, but only local differences in bedrock, surficial geology, and topography.

More importantly, figure 10 shows that values of both $\mathrm{R}_{\mathrm{a}}$ and $\mathrm{R}_{1.0}$ for the Beaver Kill at Cragie Claire (01418500) plot above both trend lines, while the same two runoff values for Willowemoc Creek near Livingston Manor (01419500) plot consistently below both trend lines. This discrepancy indicates a large difference in the amount of ground-water runoff produced from each of these subbasins from virtually the same mean annual precipitation (51.8 in. for the Beaver Kill and 52 in. for Willowemoc Creek). For example, the $\mathrm{R}_{\mathrm{a}}$ and $\mathrm{R}_{1.0}$ values for Beaver Kill at Craigie Claire (1.3 in. and 0.56 in., respectively), are significantly larger than the $\mathrm{R}_{\mathrm{a}}$ and $\mathrm{R}_{1.0}$ values Willowemoc Creek ( 0.80 and 0.44 in., respectively). These data suggests that some geologic difference between the two subbasins is producing a much greater amount of ground-water runoff (base flow) in the Beaver Kill than in Willowemoc Creek. Moreover, the larger numerical difference between the two $\mathrm{R}_{\mathrm{a}}$ values ( 0.50 in.) than for $R_{1.0}$ values ( 0.12 inches) suggests that the greatest difference in base flow between these two subbasins occurs during periods of average precipitation and average flow $\left(\mathrm{R}_{\mathrm{a}}\right.$ data), as opposed to dry conditions, represented by the $\mathrm{R}_{1.0}$ data. Although these data are not normalized to basin size, the two basins are of comparable in size-- $82 \mathrm{mi}^{2}$ for the Beaver Kill basin at Craigie Claire and $63 \mathrm{mi}^{2}$ for the Willowemoc Creek basin.

These data indicate that the Beaver Kill subbasin releases much more ground water than does 


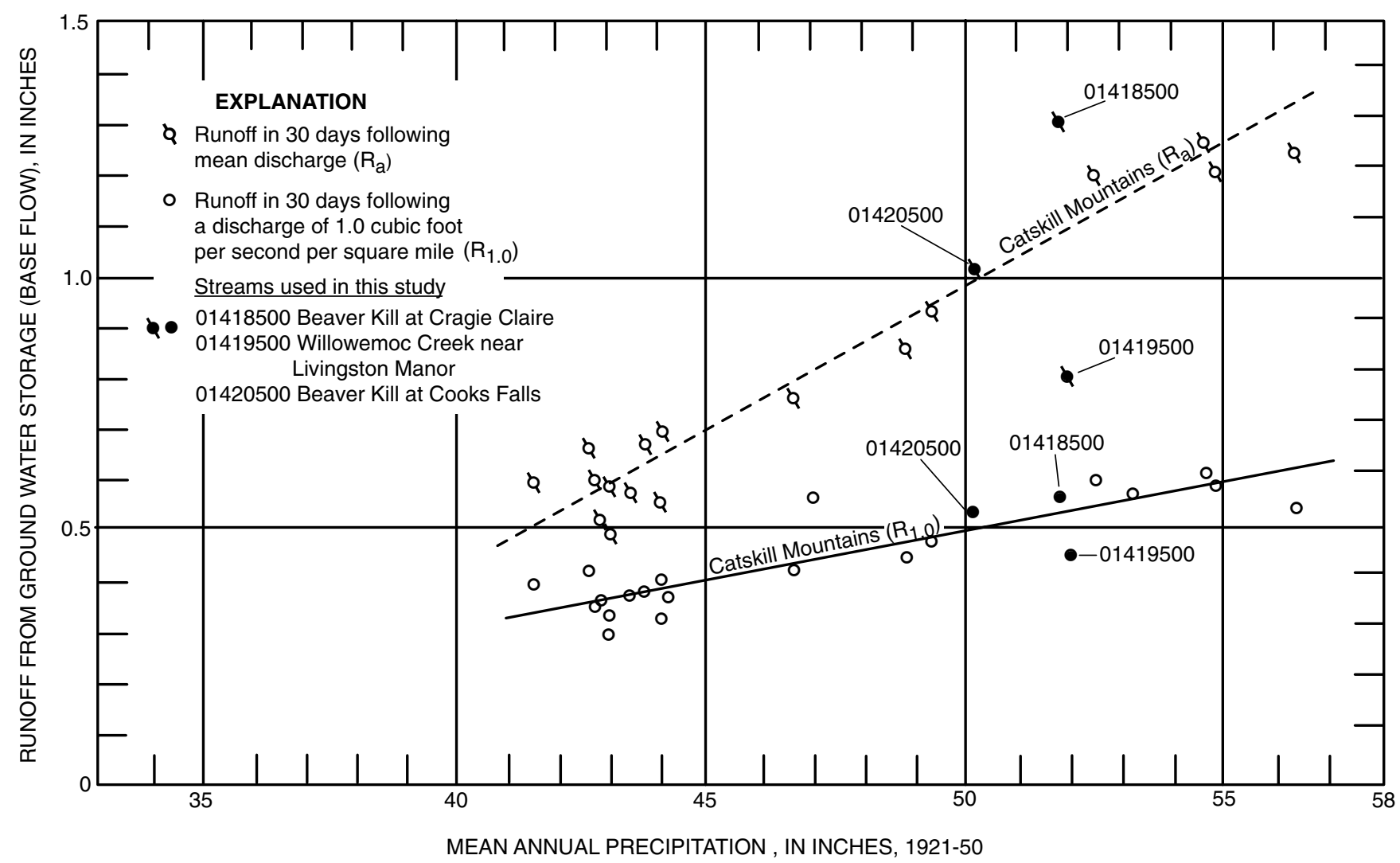

Figure 10. Relations between summer baseflow (ground-water runoff from storage) and mean annual precipitation for 23 Catskill Mountain streams, studied in Hely and Olmsted (1963).

the Willowemoc Creek subbasin during periods of average precipitation and flow, conditions, as well as during low-flow (dry) conditions, even though the Beaver Kill $\mathrm{R}_{1.0}$ data is closer to the trend line in fig. 10 (i.e., normality with comparable basins) than that for the Willowemoc Creek subbasin.

Hydrogeologic differences between the two subbasins that might account for these differences in ground-water discharge may include:

1. Surficial geology--The Beaver Kill subbasin, which drains the northern rim of the Beaver Kill basin divide, contains much larger areas of thick upland ablation and lodgment till than does the Willowemoc Creek subbasin. An analysis of the digital data used to produce the surficial geologic map in figure 2 indicates that the Beaver Kill subbasin contains $14.3 \mathrm{mi}^{2}$ of thicktill units (17.5 percent of the subbasin area), whereas the Willowemoc Creek subbasin contains only $6.1 \mathrm{mi}^{2}$ of these units $(9.8$ percent of the subbasin area).

2. Bedrock--An analysis of published bedrock maps (Fisher and others, 1970) indicates that the three bedrock formations that underlie these two subbasins are present in similar proportions. For example, the upper Walton Formation underlies approximately 47 percent of the Beaver Kill subbasin and 53 percent of the Willowemoc subbasin, and similarly, the Slide Mountain Formation underlies 38 percent of the Beaver Kill and 37 percent of the Willowemoc subbasins. The percentage of sandstone in the Beaver Kill subbasin, as measured in exposed rock faces, is a slightly higher (98 percent) than in the Willowemoc creek subbasin (91 percent) (Coates, 1971), and the sandstone in the Beaver Kill subbasin is slightly more massive than that in the Willowemoc Creek subbasin (table 1). The more massive sandstone is characterized by longer, more continuous fractures and joints, which could allow for greater storage and more rapid release of ground water following recharge events. This greater storage and more rapid release is probably the main reason for the higher base flows in the Beaver Kill than in Willowemoc Creek. 


\section{SUMMARY}

The Beaver Kill basin, which emcompasses the Beaver Kill and Willowemoc Creek subbasins, drains nearly $300 \mathrm{mi}^{2}$ of the southwestern Catskill Mountains. The most widespread surficial geologic unit, is till, being a direct result of ice-stagnation retreat. Large masses of ablation till occupy the main valleys of the Beaver Kill and Willowemoc Creek and locally reach thicknesses greater than $450 \mathrm{ft}$. These lateral embankments of till typically fill the bedrock valley such that the modern valley axis is laterally displaced as much as $1,000 \mathrm{ft}$ from the preglacial (bedrock) valley axis. Ice-contact stratified drift in the form of kame moraines, kame deltas, and kame terraces are closely associated with, and interfinger with, deposits of ablation till. A veneer of coarse outwash sand and gravel overlies till on the floor of the Beaver Kill and Willowemoc Creek valleys. The outwash is of highly variable thickness; it is typically 10 feet thick but can reach thicknesses of as much as $100 \mathrm{ft}$ locally. Saturated outwash and ice-contact stratified drift are the most productive ground-water source within the basin.

Mean annual precipitation within the Beaver Kill basin varies with elevation and ranges from $42 \mathrm{in} / \mathrm{yr}$ at the downstream (western) end of the basin to $55 \mathrm{in} / \mathrm{yr}$ at the upstream (eastern) end. Runoff also varies with basin elevation and ranges from $24 \mathrm{in} / \mathrm{yr}$ at the western end of the basin to $40 \mathrm{in} / \mathrm{yr}$ at the extreme eastern end.

A 1971 study of hydrogeologic factors that affect streamflow in the Susquehanna River basin and in Catskill (Delaware basin) streams indicates that the Beaver Kill and Willowemoc Creek have the highest mean annual discharges of 13 Catskill streams studied. The low flow that is exceeded 90 percent of the time, normalized to basin area, $\left(\mathrm{Q}_{90}\right)$ is $0.39\left(\mathrm{ft}^{3} / \mathrm{s}\right) / \mathrm{mi}^{2}$ for the Willowemoc Creek subbasin and $0.36\left(\mathrm{ft}^{3} / \mathrm{s}\right) / \mathrm{mi}^{2}$ for the Beaver Kill subbasin. These high values indicate that the dry-weather flow of both streams is sustained by ground water, discharged primarily from sandstone members of the underlying Catskill Formation, rather than from stratified drift (sand and gravel) which represents less than 5 percent of the area of both subbasins.

\section{SELECTED REFERENCES}

Coates, D.R., 1971, Hydrogeomorphology of Susquehanna and Delaware Basins, in Morisawa, Marie, Quantitative geomorphology - some aspects and applications: Proceedings of the Second Annual Geomorphology Symposia Series, Binghamton, N.Y., Oct. 15-16, 1971, State University of New York at Binghamton, p. 273-306.

Fisher, D.W., Isachsen, Y.W., and Rickard, L.V., 1970, Geologic map of New York: New York Museum and Science Service Map and Chart Series No. 15, 5 sheets, 1:250,000 scale.

Fluhr, T.W., 1948a, Memorandum on the results of a preliminary test-boring program at a proposed damsite on the Beaver Kill near Craigie Clair, Sullivan County: Unpublished report, New York City Board of Water Supply, 6 p.

, 1948b, Memorandum on the results of preliminary test-borings at the Roundtop damsite on Willowemoc Creek, Sullivan County: Unpublished report, New York City Board of Water Supply, 8 p.

,- 1949 , Memorandum on the results of preliminary borings at a proposed damsite on the Beaver Kill near Jersey Brook: Unpublished report, New York City Board of Water Supply, 6 p.

— 1953, Geology of New York City's water supply system, a progress report: The Municipal Engineers Journal, v. 39, 4th quarter, p. 125-145.

Fluhr, T.W., and Terenzio, P.E., 1984, Engineering geology of the New York City water supply system: New York State Geological Survey Open-File Report 05.08.001, $184 \mathrm{p}$.

Gubitosa, Matthew, 1980, Glacial geology of the Hancock area, western Catskills, New York: State University of New York at Binghamton, Master's thesis, $102 \mathrm{p}$.

Hely, A.G., and Olmsted, F.H., 1963, Some relations between streamflow characteristics and the environment in the Delaware River Region: U.S. Geological Survey Professional Paper 417B, 25 p.

Kipp, J.A., Lawrence, F.W., and Dinger, J.S., 1983, A conceptual model of ground-water flow in the Eastern Kentucky Coal Field, in Graves, D.H., (ed.), Symposium on Surface Mining, Hydrology, Sedimentology, and Reclamation: Lexington, Ky, University of Kentucky, Nov. 27-Dec. 2, 1983, p. 543-548.

Kirkland, J.T., 1973, Glacial geology of the western Catskills: State University of New York at Binghamton, Doctoral dissertation, $104 \mathrm{p}$.

Ozvath, D.L., 1985, Glacial geomorphology and late Wisconsinan deglaciation of the western Catskill Mountains, New York: State University of New York at Binghamton, Doctoral dissertation, $181 \mathrm{p}$. 
Ozvath, D.L., and Coates, D.R., 1986, Woodfordian stratigraphy in the western Catskill mountains, in Cadwell, D.H., The Wisconsinan stage of the First Geologic District, eastern New York: New York State Museum Bulletin No. 455, p. 109-120.

Parker, G.G., Hely, A.G., Keighton, W.B., Olmsted, F.H., and others, 1964, Water resources of the Delaware River basin: U.S. Geological Survey Professional Paper 381, 200 p.

Randall, A.D., 1996, Mean annual runoff, precipitation, and evapotranspiration in the glaciated northeastern United States, 1951-80: U.S. Geological Survey Open-File Report 96-395, 2 sheets, scale 1:1,000,000.

Randall, A.D., and Johnson, A.I., 1988, The northeast glacial aquifers RASA project--an overview of results through 1987, in Randall, A.D., and Johnson, A.I. (eds.), Regional Aquifer Systems of the United StatesThe Northeast Glacial Aquifers: American Water Resources Association Monograph Series, No. 11, p. 1-15.
Reed, G.W., and Fluhr, T.W., 1948, Memorandum on a preliminary investigation of damsites on the Beaver Kill in Sullivan County, vicinity of Craigie Claire: New York City Board of Water Supply, 6 p.

Rich, J.L., 1935, Glacial geology of the Catskills: New York State Museum Bulletin No. 299, 180 p.

Rickard, L.V., 1975, Correlation of the Siluvian and Devonian rocks in New York State: New York State Museum an Science Service Map and Chart Series, No. 24, 16 p.

Soren, Julian, 1961, The ground-water resources of Sullivan County, New York: New York State Department of Conservation Bulletin GW-46, 66 p.

,- 1963 , The ground-water resources of Delaware County, New York: New York State Department of Conservation Bulletin GW-50, 59 p.

Wandle, S.W., and Randall, A.D., 1994, Effects of surficial geology, lakes and swamps, and annual water availability on low flows of streams in central New England, and their use in low-flow estimation: U.S. Geological Survey Water Resources Investigations Report 93-4092, 57 p. 